\title{
Ultra-high performance liquid chromatography-MS/MS (UHPLC-MS/MS) in practice: analysis of drugs and pharmaceutical formulations
}

\author{
Ravsaheb H. Rathod, Suraj R. Chaudhari, Amod S. Patil and Atul A. Shirkhedkar
}

\begin{abstract}
Background: UHPLC-MS/MS is connected in various research facilities for the qualitative and quantitative investigation of a pharmaceutical substance, pharmaceutical items, and biological specimen.

Main body: The commence review article is an endeavor to offer pervasive awareness around assorted aspects and details about the UHPLC-MS/MS and related techniques with the aim on practice to an estimation of medicinal active agents in the last 10 years. The article also focused on isolation, separation, and characterization of present impurity in drug and biological samples.

Conclusion: Review article compiles a general overview of medicinally important drugs and their analysis with UHPLC-MS/MS. It gives fundamental thought regarding applications of UHPLC-MS/MS for the study on safety limit. The summary of developed UHPLC-MS/MS methods gives a contribution to the future trend and limitations in this area of research.
\end{abstract}

Key words: UHPLC-MS/MS, UHPLC, Pharmaceutical analysis, Impurity, Bio-analytical

\section{Background}

Ultra-high performance liquid-chromatography (UHPLC) covers liquid chromatography separations implementing columns enclose particles smaller than the $2.5-5 \mu \mathrm{m}$ sizes typically used in high-performance liquid chromatography (HPLC) [1]. UHPLC work on the same assumption as that of HPLC [2] and of which governing principle is that, as column packing particle size decrease, efficiency and thus resolution accretion [3]. Separations using column contain smaller particles display enhance efficiency per unit time $[1,2]$, but the efficiency cannot minimize at superior mobile phase flow rates or linear velocities [4]. After attribute, slighter particles, rapidity, and peak resolution can be absolute to new limits [5].

Since it is extremely well recognized from Van Deemter equations, the efficiency of the chromatographic process is proportional to particle size decrease [6]. Pursuant to his

\footnotetext{
* Correspondence: shirkhedkar@gmail.com

Department of Pharmaceutical Chemistry, R.C. Patel Institute of

Pharmaceutical Education and Research, Shirpur Dist., Dhule 425405, India
}

model characterized band broadening, it clarifies by the connection between height equivalent of a theoretical plate (HETP) and linear velocity, is reliant on a diameter of particle packed into the analytical column $[4,6]$. These accomplishments show the very considerable increase in resolution, sensitivity, and efficiency with the quicker outcome and a smaller amount expenditure of solvents which lowers the cost and make the technology environment friendly [7].

The hyphenated technique has turned out a precious method for the assessment of pharmaceuticals in various biological samples. The hyphenated technique is an attachment of the chromatographic system linked with the spectroscopic system with the right interface, such as LC-MS/MS [8]. It is well known that the detection profit appreciably from the performance characteristics of the UHPLC technology. As there is reduced in chromatography dispersion with an increased concentration of analyte will encourage improved source ionization efficiency [5]. 
Table 1 Acceptance criteria for UPLC-MS/MS

\begin{tabular}{ll}
\hline Characteristics & UHPLC \\
\hline Particle size & $<2 \mu \mathrm{m}$ \\
Maximum back pressure & $1000 \mathrm{bars}$ \\
Analytical column & UHPLC BEH C 18 \\
Column dimensions & $50 \times 2.1 \mathrm{~mm}$ \\
Injection volume & $2 \mu \mathrm{L}$ \\
Column temperature & $65{ }^{\circ} \mathrm{C}$ \\
Total run time & $1.5 \mathrm{~min}$ \\
USP resolution & 3.4 \\
Plate count & 7500 \\
Flow rate & $0.6 \mathrm{~mL} / \mathrm{min}$ \\
\hline
\end{tabular}

The hyphenated techniques usually applied for identification as well as quantification of the analyte when it is compared with other analytical methods [8]. At present era, employing of UHPLC gives the full benefits of chromatography applications for the separations using shorter columns, and superior flow rates for augmented rapidity, with greater resolution and sensitivity. The recognition criterion of UHPLC-MS/MS is shown in Table 1 [7]. The current review recapitulates the applications of UHPLC-MS/MS method for assessing drug in pharmaceutical as well as the biological matrix. In literature, there are several methods reported for analysis of drugs using UHPLC-MS/MS, the major categorized such as antidiabetic, anticancer, antibiotics, cardiovascular, antiviral, nonsteroidal anti-inflammatory drug (NSAID), and others.

\section{Main text UHPLC columns}

The Acquity UHPLC column involved in the front line of liquid chromatography (LC) column development by giving higher quality chromatographic data's in less time. For use in applying up to 15000 psi (1000 bar), UHPLC columns are designed, certified, and tested [9]. However, different technologies produced distinct nature of columns actuality used in UHPLC is depicted in Fig. 1.

\section{Charged surface hybrid}

Third-generation particle technology was developed by waters, designed to recover sample loadability and peak tailing in uncertain ionic strength mobile phase composition. The charged surface hybrid retains the low level surface charge with $1.7 \mu \mathrm{m}$ particle size [9]. The basic charged surface hybrid ( $\mathrm{CSH}$ ) $\mathrm{C}_{18}$ column characteristics such as peak shape and increased loading capacity, mainly for basic compounds under low-pH, weak-ionicstrength mobile-phase [10]. The polyaromatic compound selective straight-chain-alkyl is especially used in Acquity UHPLC CSH Phenyl-Hexyl column and also it

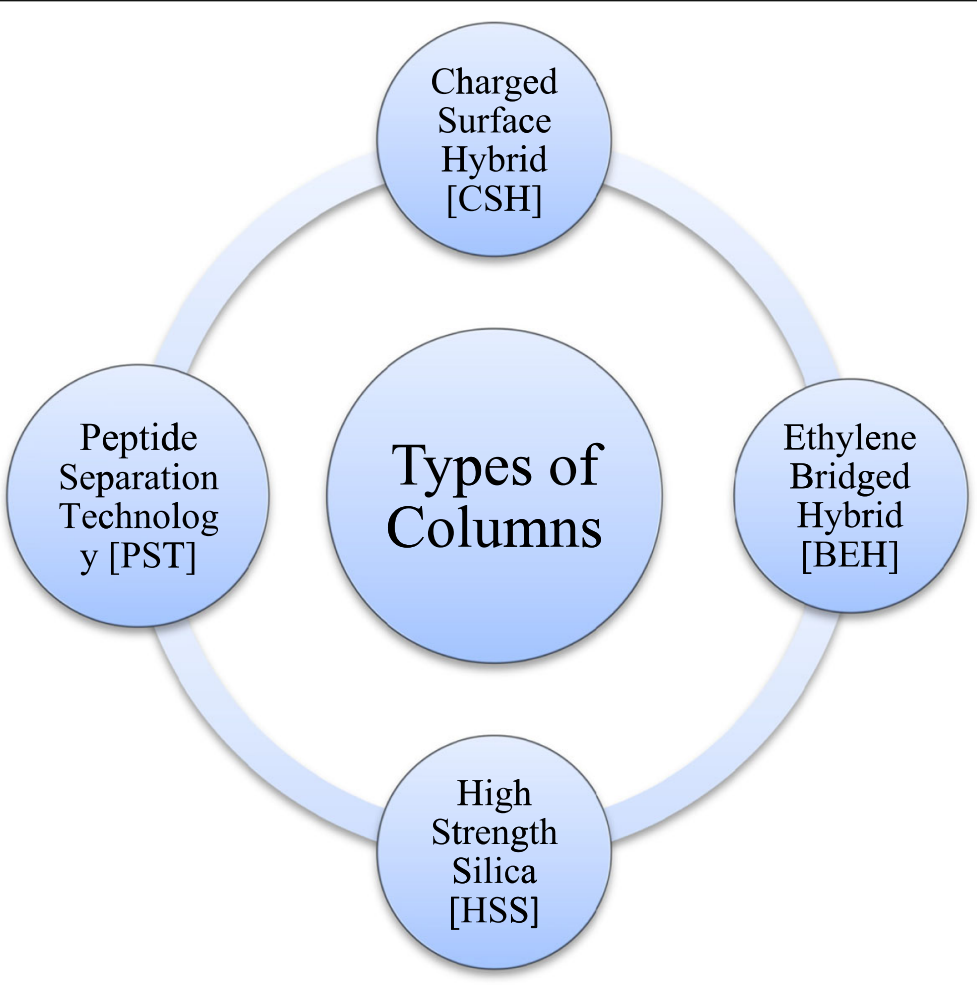

Fig. 1 Types of UHPLC columns 
gives exceptional peak shape under different $\mathrm{pH}$ conditions [10]. The Acquity UHPLC CSH Fluoro-Phenyl columns show excellent selectivity for polar compounds, positional isomer, and halogenated compounds. This is due to a dipole-dipole, hydrogen-bonding, aromatic, and hydrophobic interaction [10].

\section{Ethylene-bridged hybrid}

The deficiency of mechanical strength or efficacy is essential to complete the potential speed, sensitivity, and resolution capabilities for primary generation methylhybrid particle of xTerra columns. Hence, there is need of a column with a new pressure-tolerant particle needed to create. An innovative, additional hybrid material columns were set that contains an ethylenebridged hybrid material. It displayed enhanced efficiency, $\mathrm{pH}$ range, and strength as compared to first-generation columns [11]. The developed ethylene-bridged hybrid (BEH) columns fixed polar group attached to the silyl functionality with a $\mathrm{C}_{6}$ alkyl and also for UHPLC BEH phenyl columns [7].

\section{High strength silica}

High strength silica (HSS) is another type of column used in UHPLC. In UHPLC, high pore volume UHPLC particles do not acquire the mechanical stability necessary to hold up the high pressure innate of UHPLC separations [9]. For that, there is established a novel silica particle and appropriate morphology required to give long and lifetime efficiency UHPLC column at high pressure likely 1000 bars. HSS particle technology is the modern automation; $1.8 \mu \mathrm{m}$ UHPLC HSS particles are designed and exclusively for separations using UHPLC [12]. To overcome trouble during separation and retention of small water-soluble and polar organic molecules during reversed phase separation, Acquity UHPLC HSS $\mathrm{T}_{3}$ columns were developed. The Acquity UHPLC HSS $\mathrm{C}_{18}$ selectivity for bases (SB) columns is a nonendcapped, low-coverage silica-based $\mathrm{C}_{18}$ chemistry that alternate selectivity for water-soluble compounds influenced by silanophilic interactions. The enhanced silanol activity of the HSS $\mathrm{C}_{18} \mathrm{SB}$ column result in greater retention of basic compounds; due to secondary interactions with residual silanols while simultaneously

Table 2 Present perspective on UHPLC-MS/MS methods

\begin{tabular}{|c|c|c|c|}
\hline Author(s) & Title & Year & Ref \\
\hline Tatsuya Higashi, Kazutake Shimada, Toshimasa Toyo'oka & $\begin{array}{l}\text { Advances in determination of vitamin D related } \\
\text { compounds in biological samples using liquid } \\
\text { chromatography-mass spectrometry: a review }\end{array}$ & 2009 & [20] \\
\hline Aurelie Roux, Dominique Lison, Christophe Junot, Jean-François Heilier & $\begin{array}{l}\text { Applications of liquid chromatography coupled } \\
\text { to mass spectrometry-based metabolomics in } \\
\text { clinical chemistry and toxicology: a review }\end{array}$ & 2010 & [21] \\
\hline $\begin{array}{l}\text { Alexander A. Zoerner, Frank-Mathias Gutzki, Sandor Batkai, Marcus } \\
\text { May, Christin Rakers, Stefan Engeli, Jens Jordan, Dimitrios Tsikas }\end{array}$ & $\begin{array}{l}\text { Quantification of endocannabinoids in biological } \\
\text { systems by chromatography and mass spectrometry: } \\
\text { a comprehensive review from an analytical and } \\
\text { biological perspective }\end{array}$ & 2011 & [22] \\
\hline Fabio Gosetti, Eleonora Mazzucco, Maria Carla Gennaro, Emilio Marengo & $\begin{array}{l}\text { Ultra high performance liquid chromatography } \\
\text { tandem mass spectrometry determination and } \\
\text { profiling of prohibited steroids in human biological } \\
\text { matrices. a review }\end{array}$ & 2012 & [23] \\
\hline Marcus Bantscheff \& Simone Lemeer \& Mikhail M. Savitski \& Bernhard Kuster & $\begin{array}{l}\text { Quantitative mass spectrometry in proteomics: } \\
\text { critical review update from } 2007 \text { to the present }\end{array}$ & 2012 & [24] \\
\hline Mark R. Viant, Ulf Sommer & $\begin{array}{l}\text { Mass spectrometry based environmental metabolomics: } \\
\text { a primer and review }\end{array}$ & 2012 & [25] \\
\hline Maria-Jose Motilva, Aida Serra, Alba Macia & $\begin{array}{l}\text { Analysis of food polyphenols by ultra high-performance } \\
\text { liquid chromatography coupled to mass spectrometry: } \\
\text { an overview }\end{array}$ & 2013 & [26] \\
\hline Nikalje Anna Pratima, Baheti Shraddha, Sayyad Zibran & $\begin{array}{l}\text { Review of ultra performance liquid chromatography } \\
\text { and its applications }\end{array}$ & 2013 & [27] \\
\hline $\begin{array}{l}\text { Maria Joao Gouveia, Paul J. Brindley, Lucio Lara Santos, Jose Manuel } \\
\text { Correia da Costa, Paula Gomes, Nuno Vale }\end{array}$ & $\begin{array}{l}\text { Mass spectrometry techniques in the survey of } \\
\text { steroid metabolites as potential disease biomarkers: } \\
\text { a review }\end{array}$ & 2013 & [28] \\
\hline $\begin{array}{l}\text { Muchena J. Kailemia, L. Renee Ruhaak, Carlito B. Lebrilla, and I. } \\
\text { Jonathan Amster }\end{array}$ & $\begin{array}{l}\text { Oligosaccharide analysis by mass spectrometry: a } \\
\text { review of recent developments }\end{array}$ & 2013 & [29] \\
\hline Linda Kortz, Juliane Dorow, Uta Ceglarek & $\begin{array}{l}\text { Liquid chromatography-tandem mass spectrometry } \\
\text { for the analysis of eicosanoids and related lipids in } \\
\text { human biological matrices: a review }\end{array}$ & 2014 & [30] \\
\hline
\end{tabular}




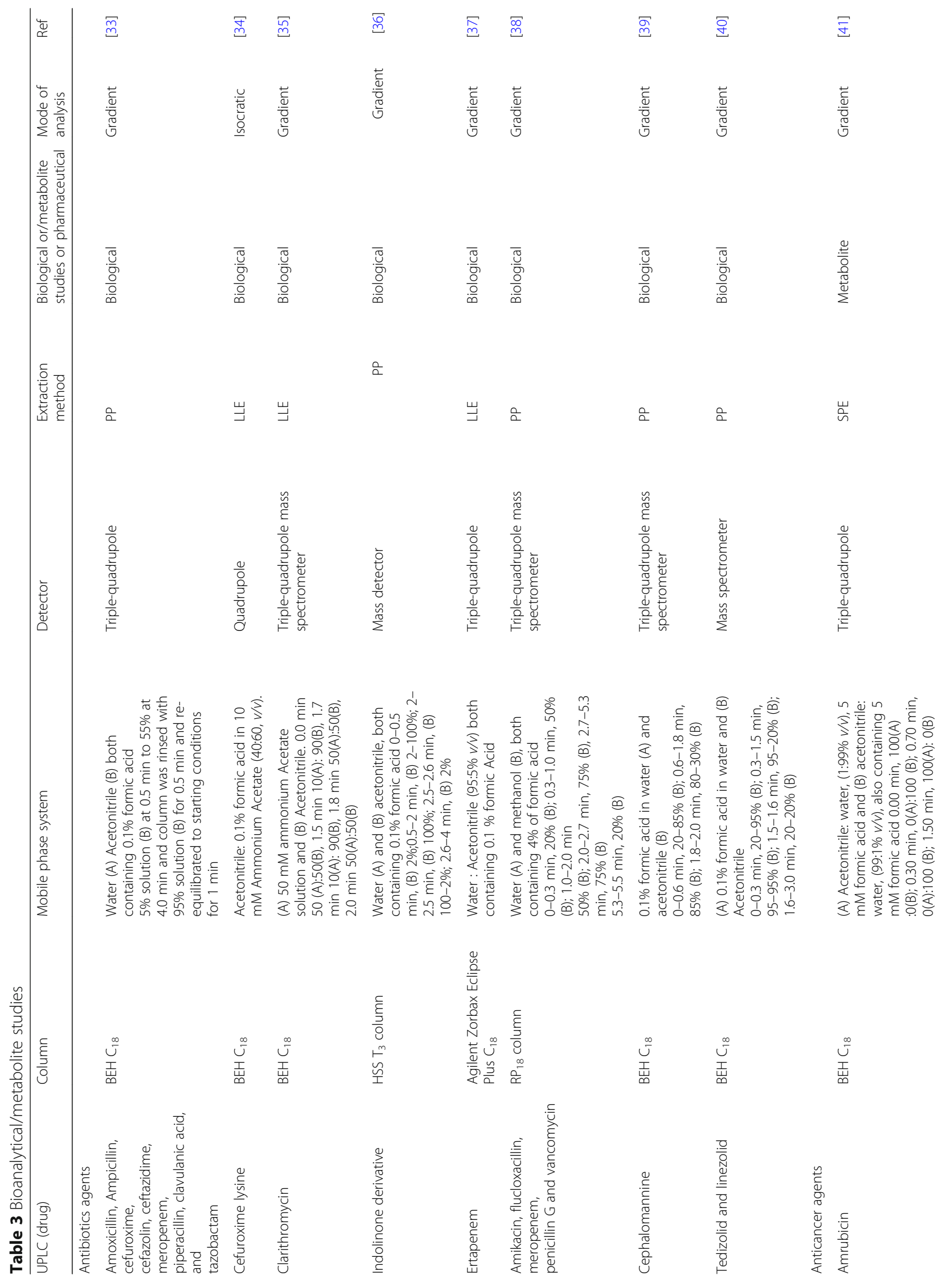




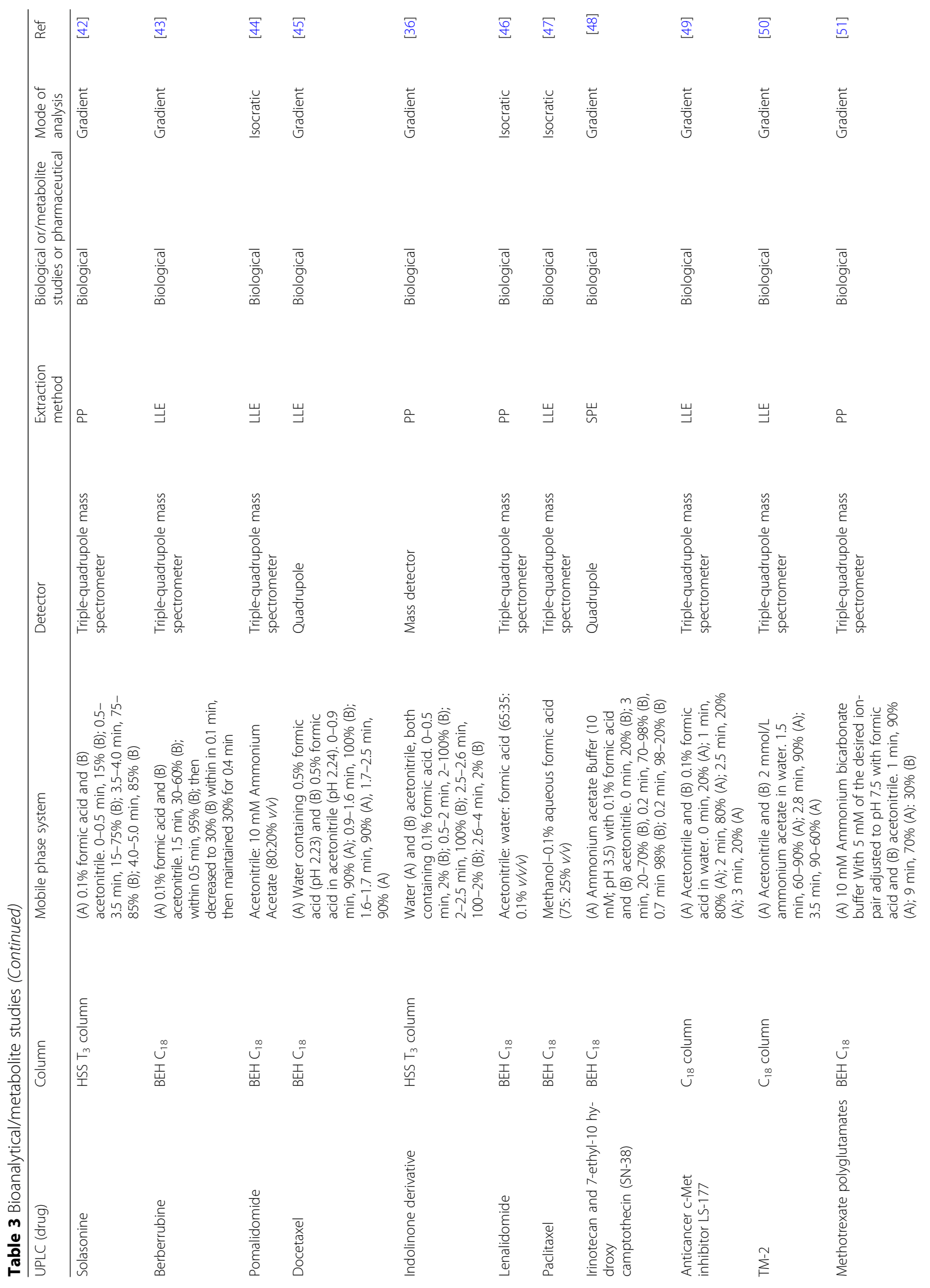




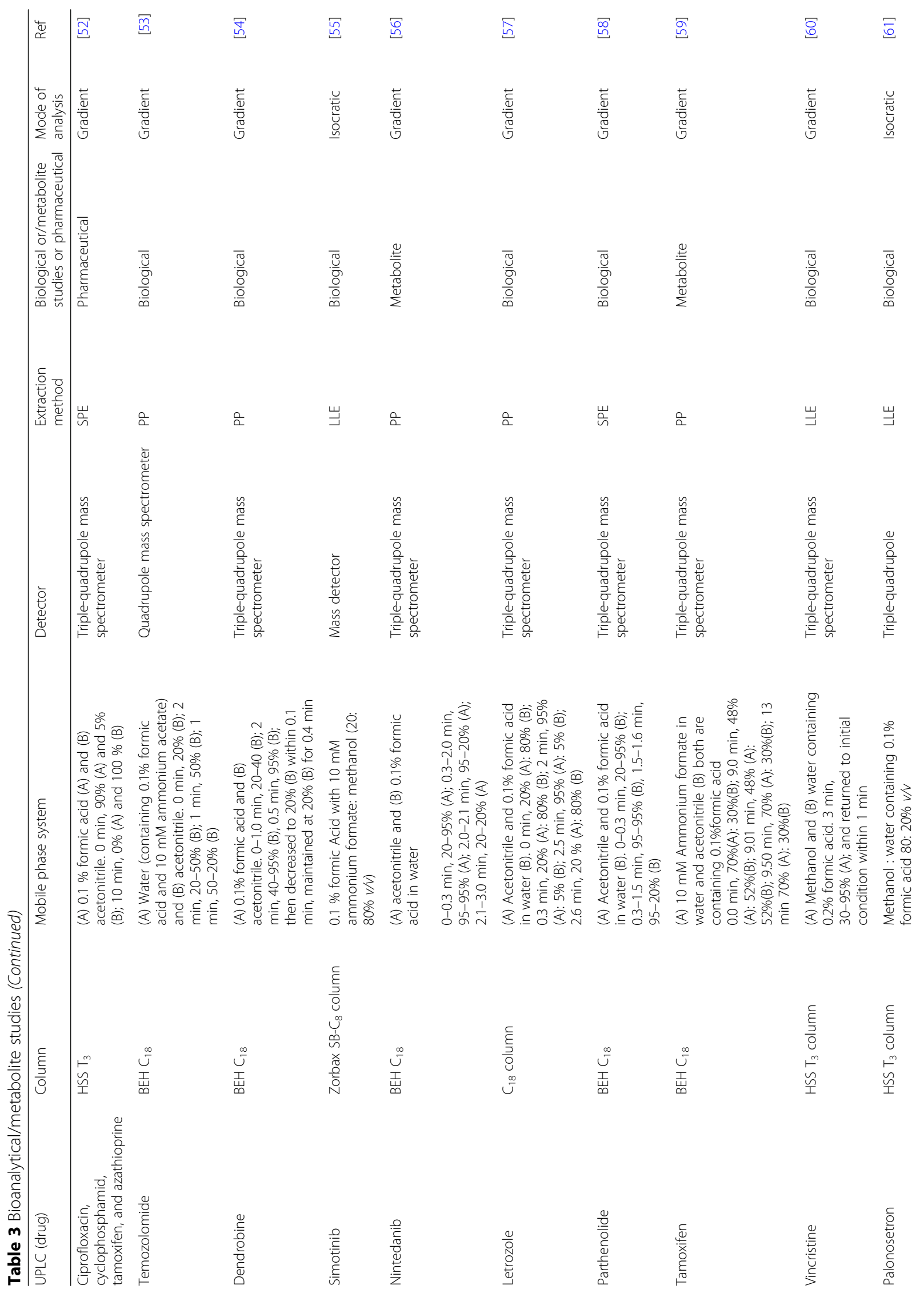




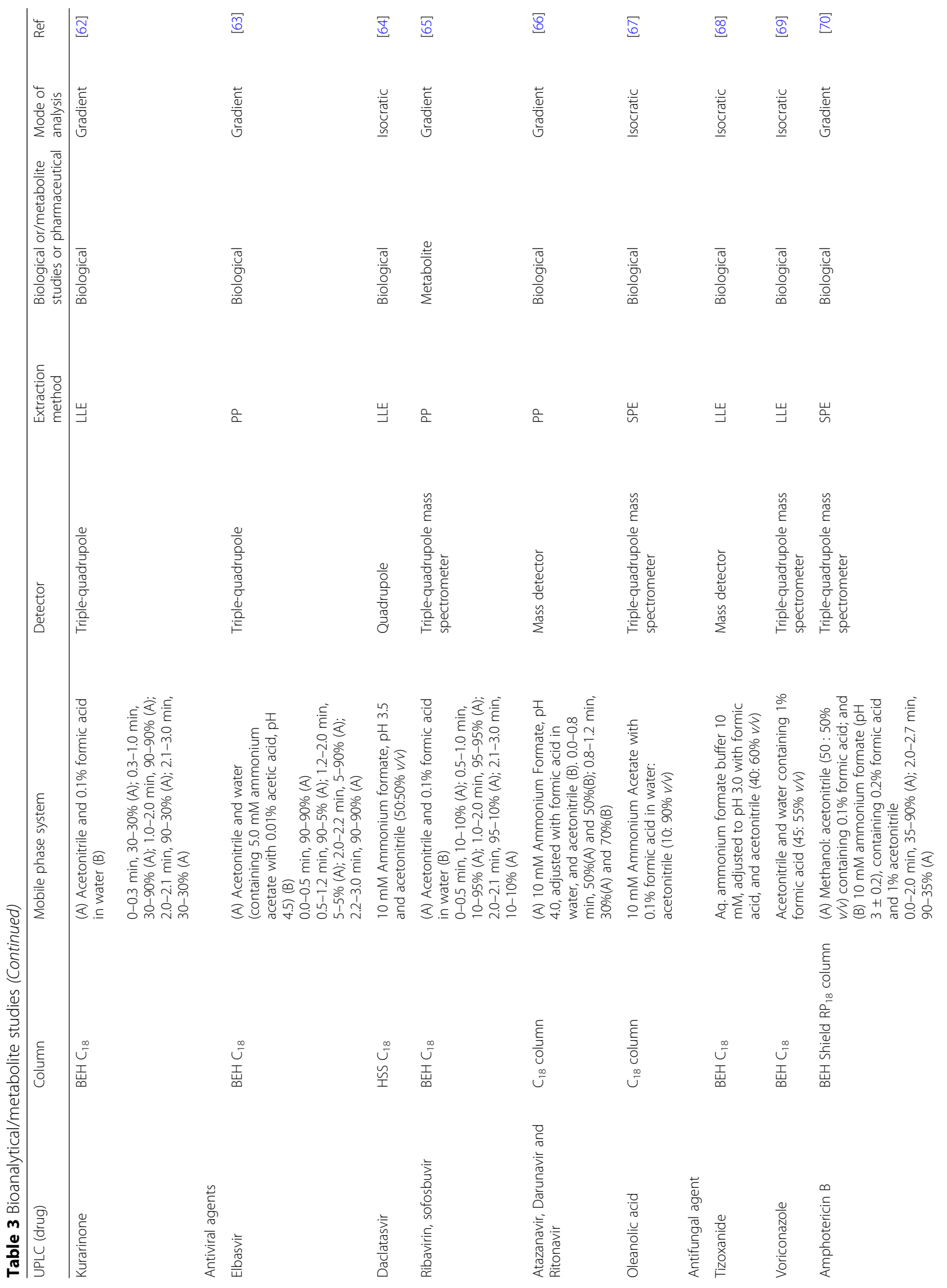




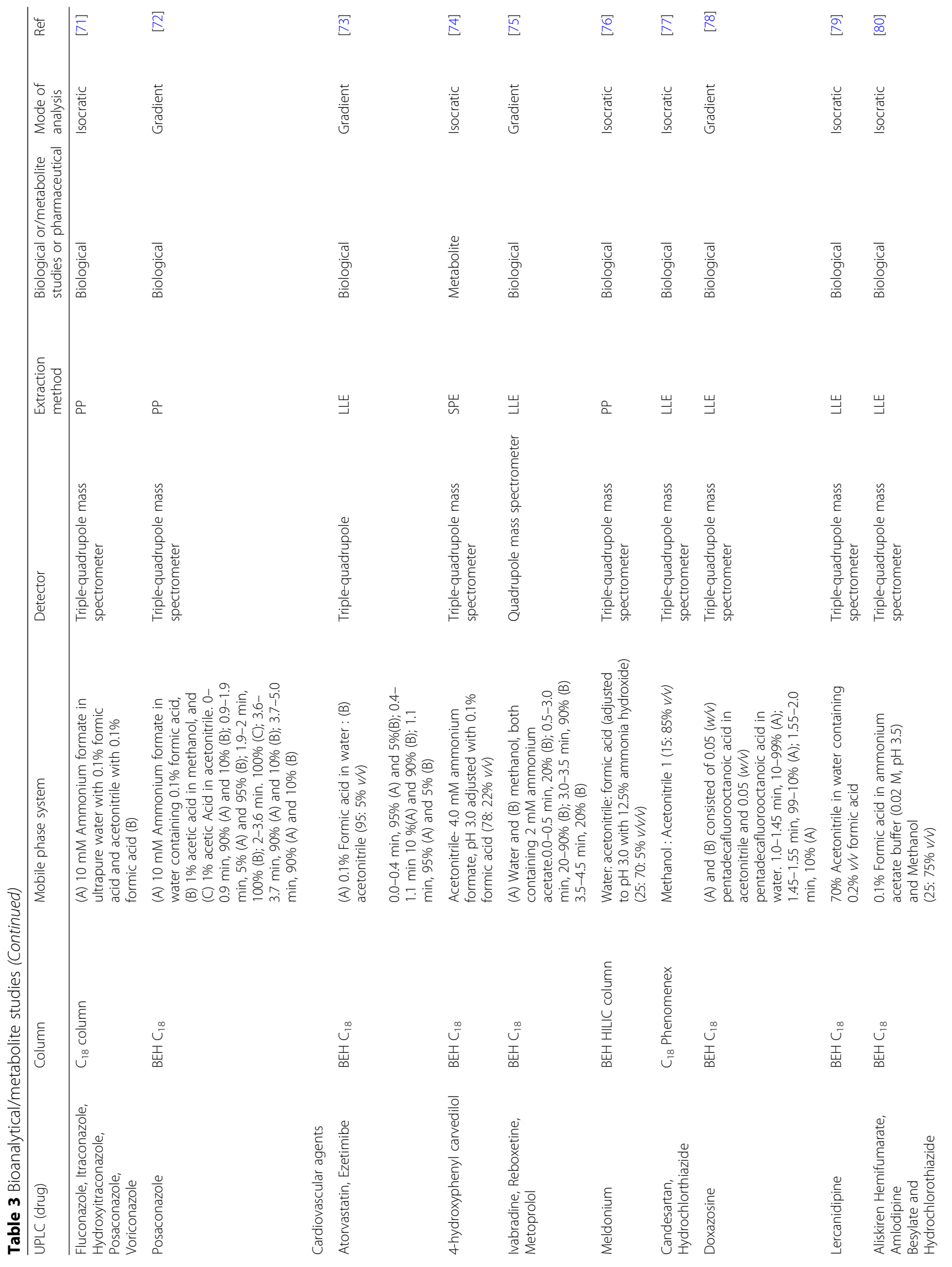




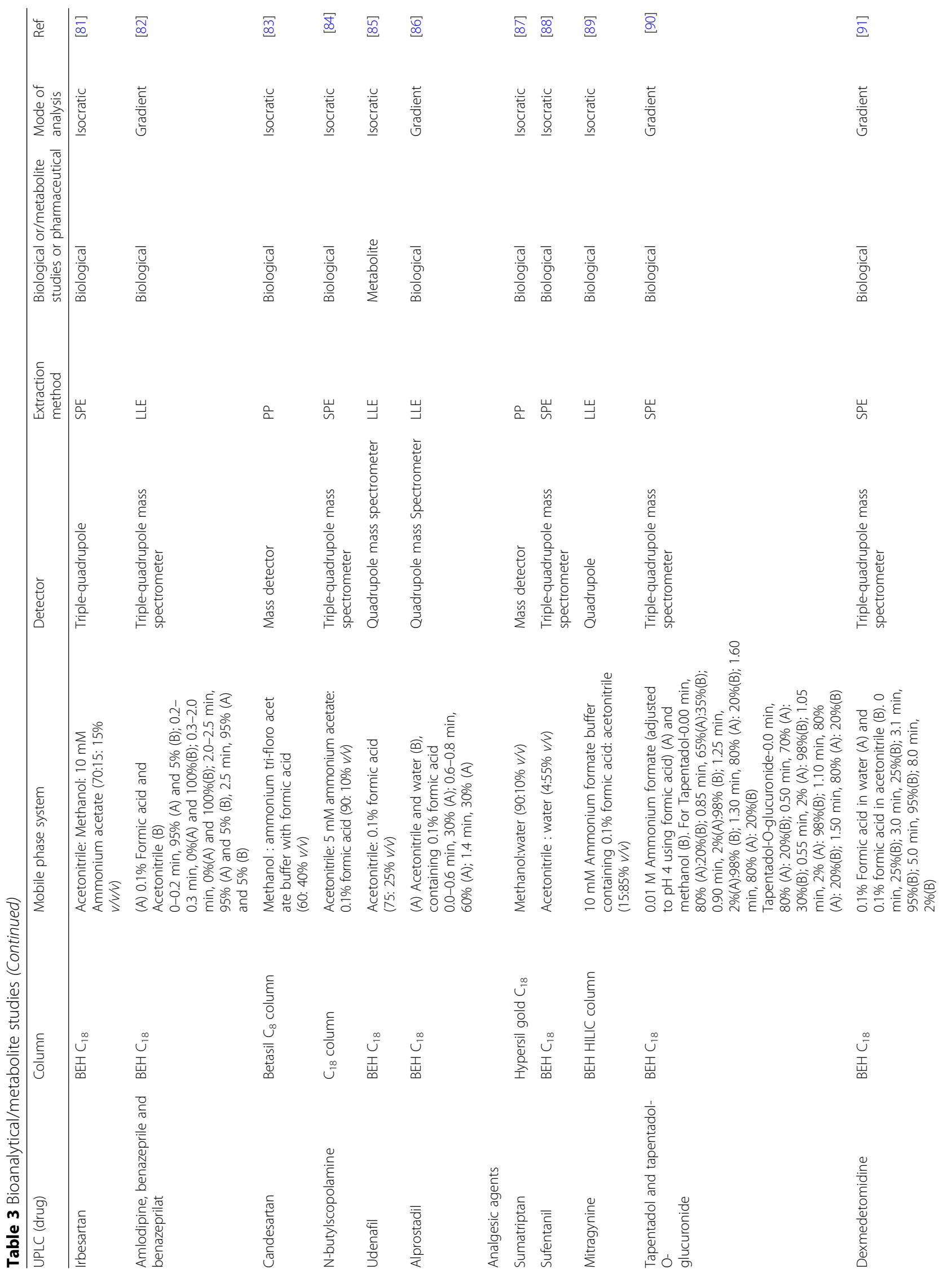




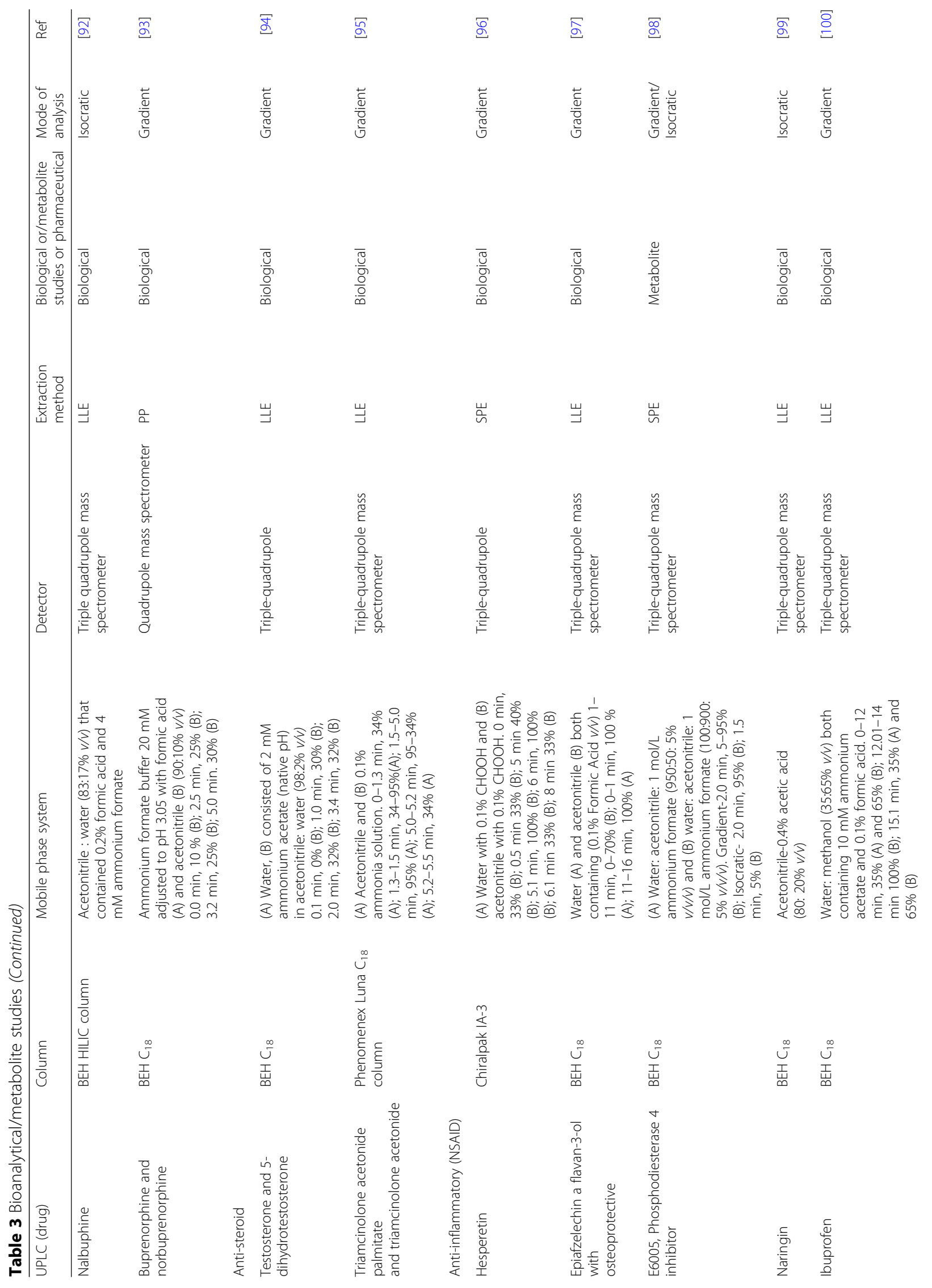




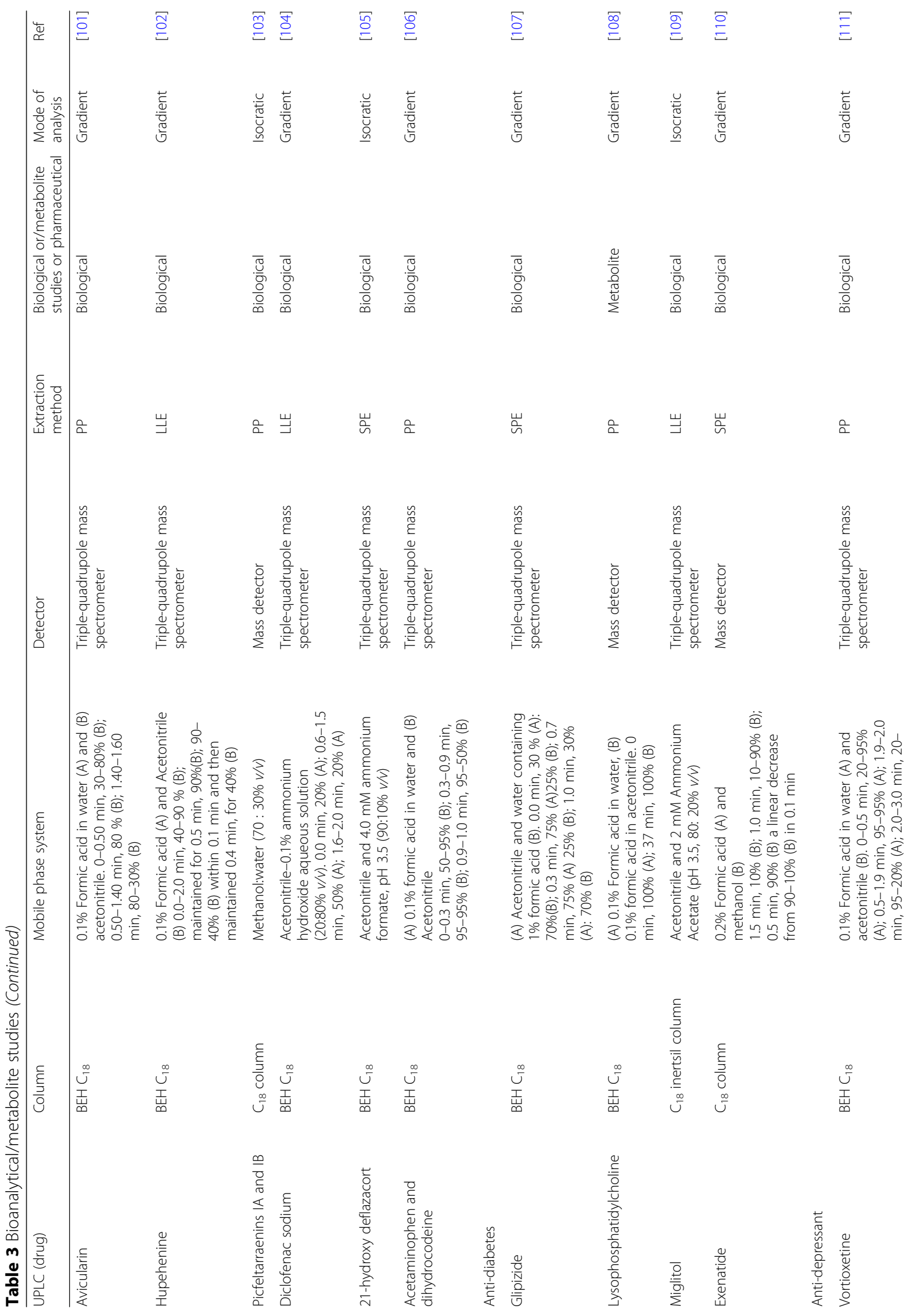




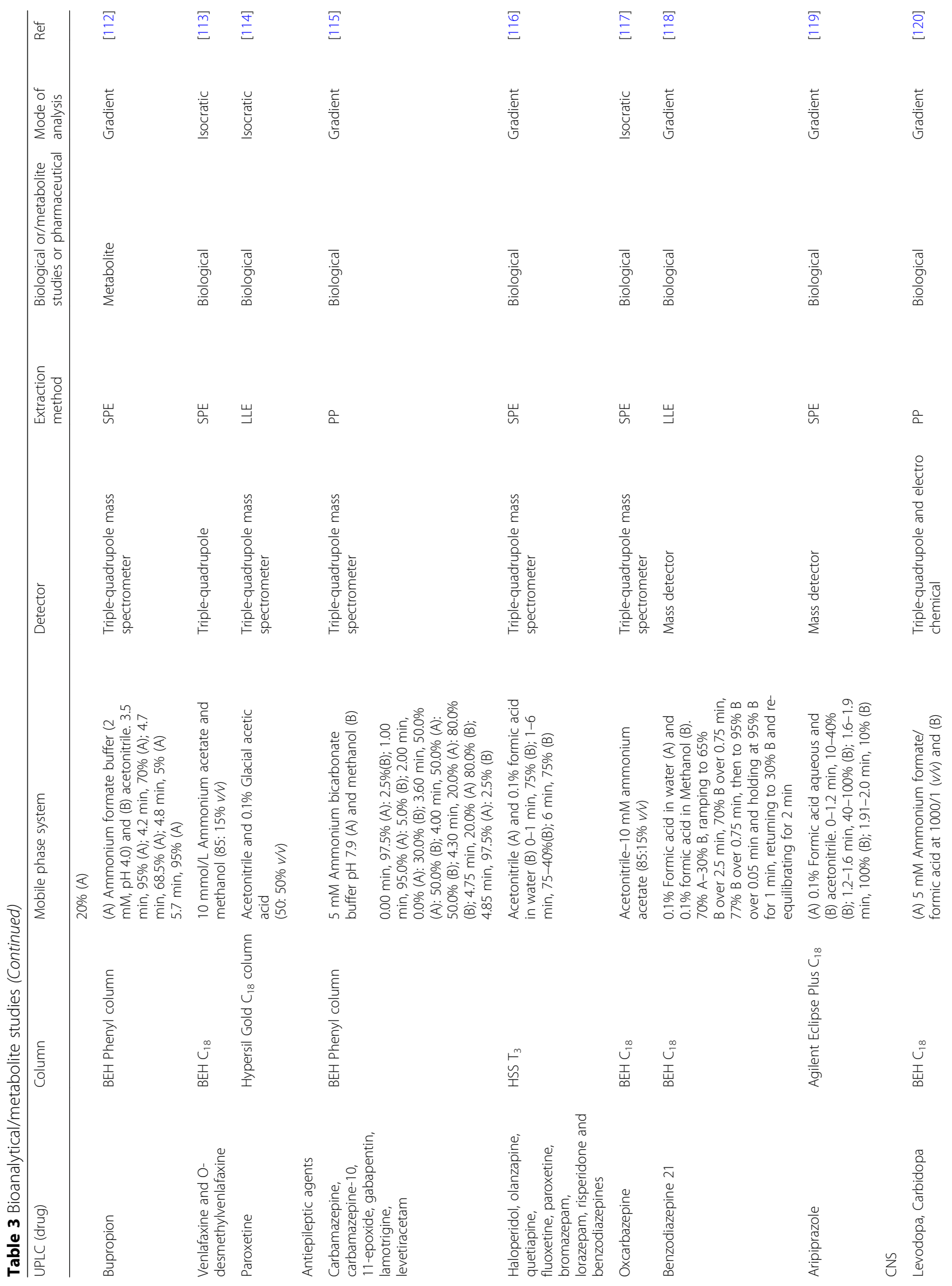




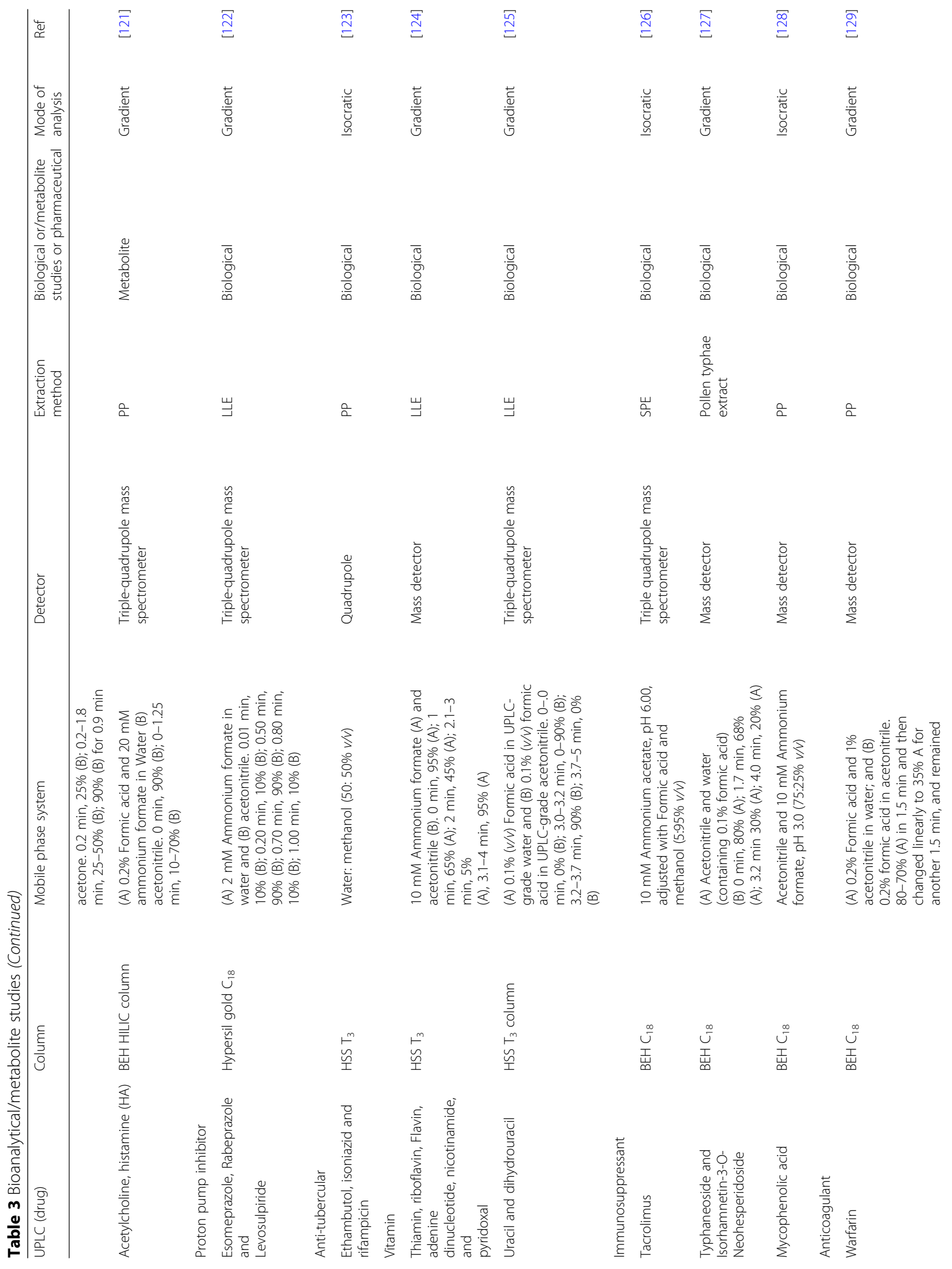




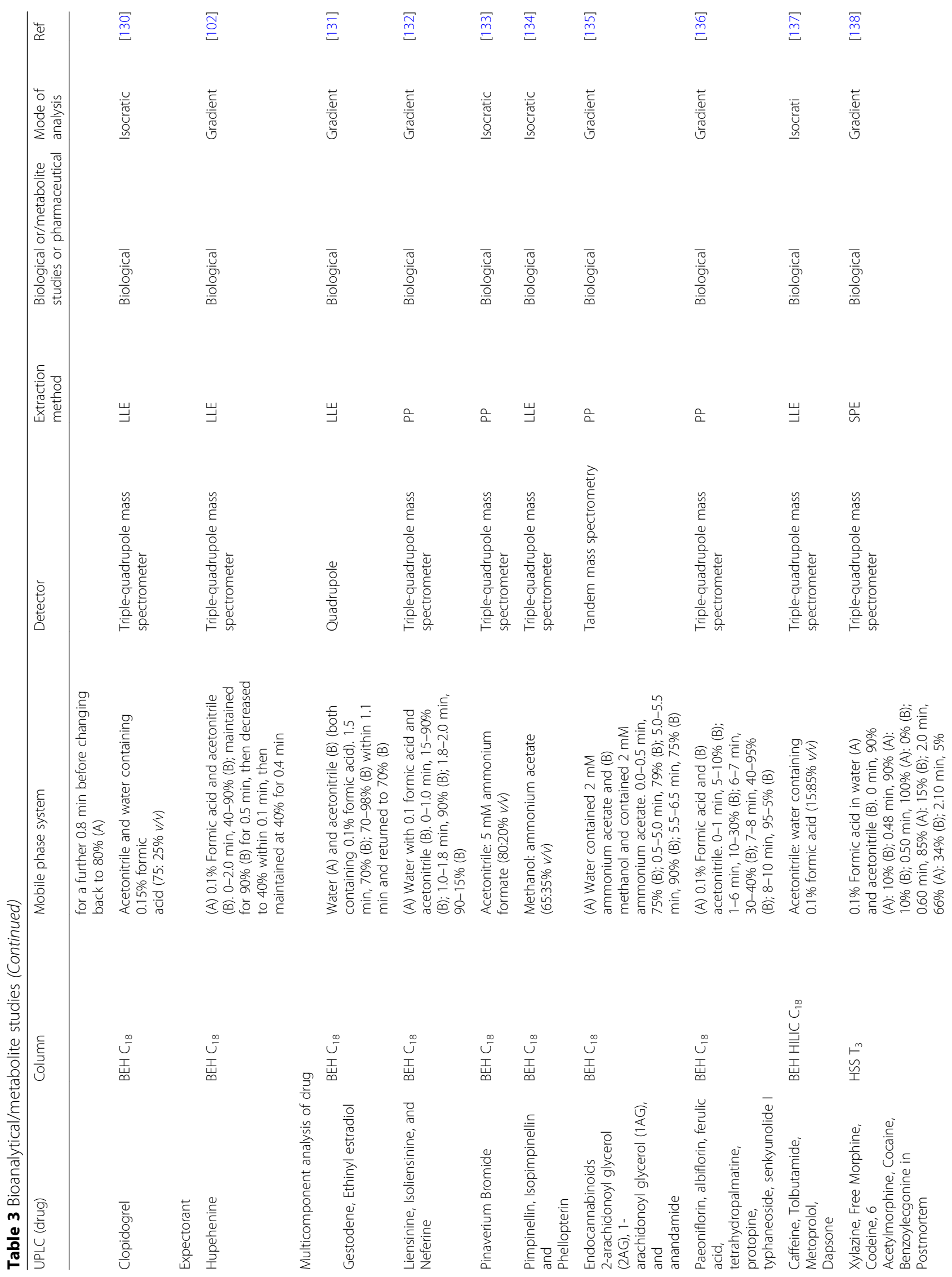




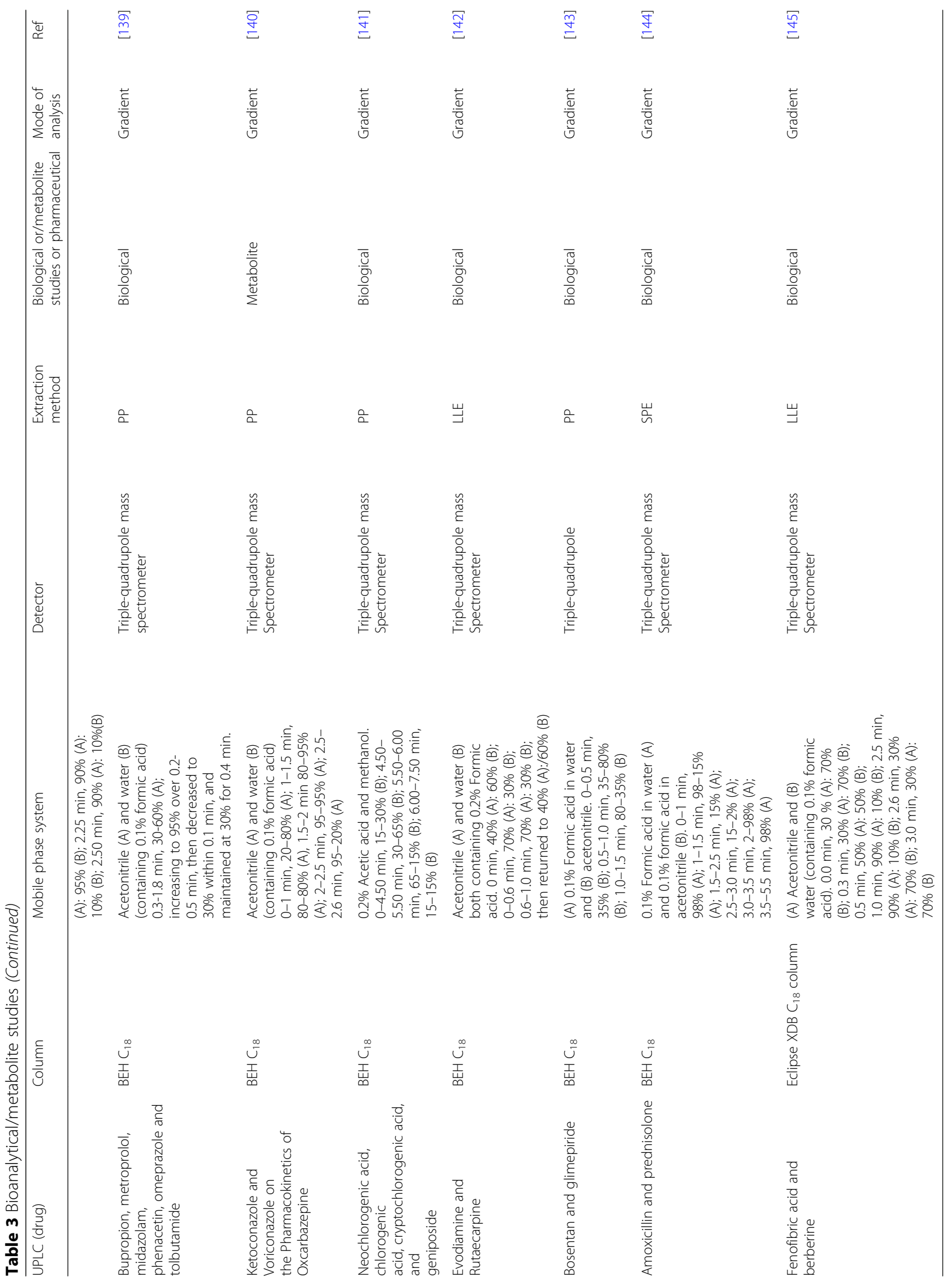




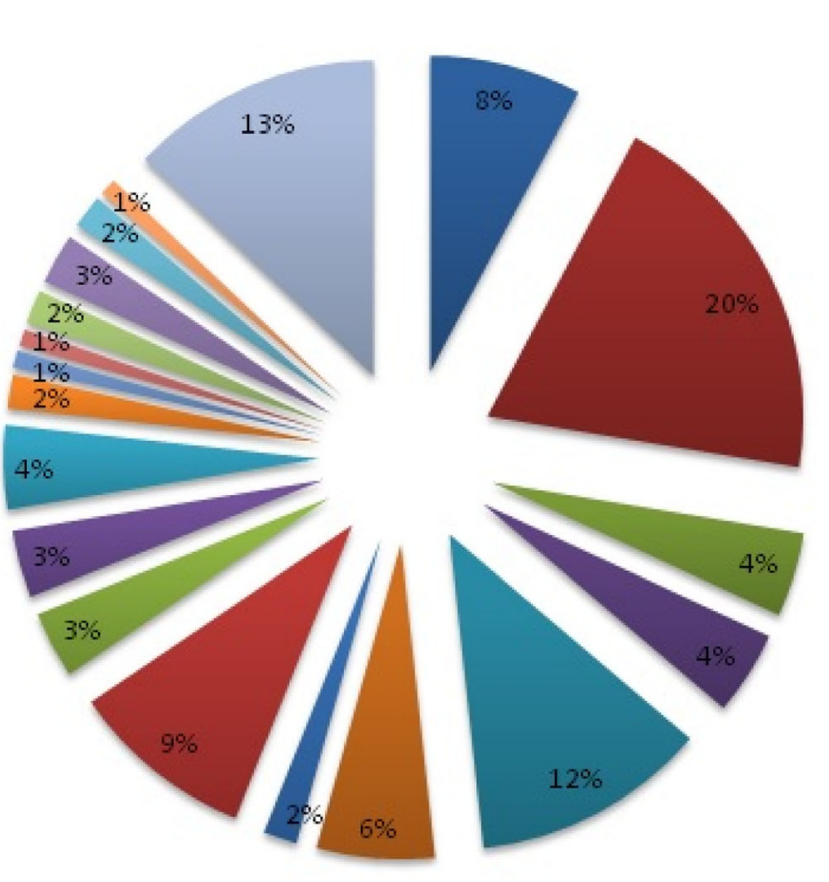

Antibiotics

- Anticancer

Antiviral

- Antifungal

- Cardiovascular

Analgesic

- steroid

NSAID

Diabetes

Anti-depressant

- Antiepileptic

ans

- Proton pump inhibitor

anti-tubercular

vitamin

Immunosuppressant

Fig. 2 Analysis of different classes of drugs using UHPLC-MS/MS in between 2006-2017

Table 4 Stability-indicating method UHPLC-MS/MS

\begin{tabular}{|c|c|c|c|c|c|c|}
\hline Drug & $\begin{array}{l}\text { Acid } \\
\text { degradation }\end{array}$ & $\begin{array}{l}\text { Base } \\
\text { degradation }\end{array}$ & $\begin{array}{l}\text { Photo- } \\
\text { degradation }\end{array}$ & $\begin{array}{l}\text { Oxidative } \\
\text { degra. }\end{array}$ & Detection & Ref \\
\hline Conditions & 0.1 to $1 \mathrm{~N}$ & 0.1 to $2 \mathrm{M}$ & Light & $\begin{array}{l}\mathrm{H}_{2} \mathrm{O}_{2} \text { and } \\
\mathrm{KMnO} 4\end{array}$ & - & - \\
\hline Fluticasone Propionate & 7 days & $\left(50^{\circ} \mathrm{C}\right) 24 \mathrm{~h}$ & - & - & $\begin{array}{l}\text { Thioester, Carboxylic ester, } \\
\text { alcohol, ketone, diol }\end{array}$ & [147] \\
\hline Duloxetine & $\left(50^{\circ} \mathrm{C}\right) 24 \mathrm{~h}$ & 7 days & - & - & Ether,1-naphthol & \\
\hline Amlodipine & $24 \mathrm{~h}$ & $24 \mathrm{~h}$ & - & - & 1,4-dihydropyridine ring & \\
\hline Moxonidine & $\begin{array}{l}(0.5 \mathrm{M}) \mathrm{HCl} \\
80 \mathrm{~min}\end{array}$ & $\begin{array}{l}2 \mathrm{M} \mathrm{NaOH} \text { at } \\
70{ }^{\circ} \mathrm{C} \text { for } 15 \mathrm{~min}\end{array}$ & 7 days at $80^{\circ} \mathrm{C}$ & $\mathrm{H}_{2} \mathrm{O}_{2} 5 \mathrm{~h}$ & Impurity-A and impurity-D & [148] \\
\hline Rivaroxaban & $\begin{array}{l}\left(60^{\circ} \mathrm{C}\right) \\
6-24 \mathrm{~h}\end{array}$ & $\left(60^{\circ} \mathrm{C}\right) 1-6 \mathrm{~h}$ & $2-5 \mathrm{~h}(254 \mathrm{~nm})$ & - & $\begin{array}{l}\text { Morpholinone moiety, } \\
\text { oxazolidinone ring, } \\
\text { chlorothiophene carbonyl. }\end{array}$ & [149] \\
\hline $\begin{array}{l}\text { Ciprofloxacin,Moxifloxacin, } \\
\text { Norfloxacin, Ofloxacin }\end{array}$ & - & - & 105-113 day & - & $\begin{array}{l}\text { CP-1 - CP-6 and OP-1 - OP-6, } \\
\text { NP-1 - NP-5 MP-1 and MP-10 }\end{array}$ & [150] \\
\hline Hexazinone & - & - & $\begin{array}{l}\text { Degussa } \mathrm{P} 25 \text { and } \\
\text { the nano- } \mathrm{TiO}_{2} .40 \text { min } \\
\text { complete degradation }\end{array}$ & - & $\begin{array}{l}\text { Methylamine, triazinone, } \\
\text { urea, carbon dioxide. }\end{array}$ & [151] \\
\hline $\begin{array}{l}\text { Ciprofloxacin, Difloxacin, } \\
\text { Lomefloxacin, Norfloxacin, } \\
\text { and Ofloxacin }\end{array}$ & - & - & - & $\begin{array}{l}\mathrm{KMnO}_{4} \text { in acidic } \\
\mathrm{pH}(3-6)\end{array}$ & $\begin{array}{l}\mathrm{N}-1 \text { and } \mathrm{N}-4 \text { piperazine atoms } \\
\text { and 3- monohydroxylated } \\
\text { products 3-hydroxy-5-oxo } \\
\text { derivatives }\end{array}$ & [152] \\
\hline Ampicillin & $\left(60^{\circ} \mathrm{C}\right) 4 \mathrm{~h}$ & $\left(60^{\circ} \mathrm{C}\right)$ for $4 \mathrm{~h}$ & - & - & $\begin{array}{l}\text { 2-(acetamidomethyl)-5,5- } \\
\text { dimethylthiazolidine- } \\
\text { 4-carboxylate 1, 1-dioxide }\end{array}$ & [153] \\
\hline
\end{tabular}


Table 5 Impurity profile of drug using UHPLC-MS/MS

\begin{tabular}{|c|c|c|c|c|}
\hline Sr. no & Drug(s) & Detection wavelength & $\begin{array}{l}\text { Name of impurity/number } \\
\text { of impurities detected }\end{array}$ & References \\
\hline 1 & Finasteride & $210 \mathrm{~nm}$ & 4 & [154] \\
\hline 2 & Famotidine & $265 \mathrm{~nm}$ & Imines & [155] \\
\hline 3 & Desloratadine & $280 \mathrm{~nm}$ & 5 & [156] \\
\hline 4 & $\begin{array}{l}\text { Sitagliptin, vildagliptin, } \\
\text { and metformin }\end{array}$ & $210 \mathrm{~nm}$ & 2 & [157] \\
\hline 5 & Heroin & - & Acidic and neutral impurity & [158] \\
\hline 6 & Dabigatran Etexilate & $220 \mathrm{~nm}$ & 3 & [159] \\
\hline 7 & Zolmitriptan & - & 4 & [160] \\
\hline 8 & Smokeless powder & $210 \mathrm{~nm}$ & $\begin{array}{l}\text { Nitroglycerin (NG), 2,4- } \\
\text { dinitrotoluene (2,4-DNT), and } \\
\text { 2,6-dinitrotoluene (2,6-DNT) }\end{array}$ & [161] \\
\hline 9 & Ritonavir & $240 \mathrm{~nm}$ & 13 & [162] \\
\hline 10 & $25-\mathrm{OCH}_{3}-\mathrm{PPD}$ & $495 \mathrm{~nm}$ & 3 & [163] \\
\hline
\end{tabular}

reducing the retention of non-basic analytes due to the low ligand density and ionic repulsion [10].

\section{Peptide separation technology}

The separation or isolation of different peptides, the peptide-based peptide separation technology columns, was utilized for analysis of peptides. Developed peptide separation technology (PST) columns are $\mathrm{C}_{18} \mathrm{BEH}$ Technology, in PST column particles sizes in the variety of $1.7 \mu \mathrm{m}$ to $10 \mu \mathrm{m}$ and the column dimension ranges from $75 \mu \mathrm{m}$ to $30 \mathrm{~mm}$ internal diameter and column length from 50 to $250 \mathrm{~mm}$. The PST columns demonstrate sharp-edged symmetrical peaks [7].

\section{UHPLC, superior technique than HPLC}

The UHPLC system is superior to HPLC system because the UHPLC system operates at high pressure up to 1000 bar or more than that, but a conventional HPLC system, compass a pressure up to 400 bars and it suffers problems like mobile phase swallowing and increases the time of analysis. But in UHPLC system, less solvent consumption and less time for analysis are required [13]. This could unlikely outstanding use of slighter particles less than $2.0 \mathrm{~mm}$ and also at tolerable flow up to $5 \mathrm{~mL} /$ min. The use of the lesser particle size shows better resolution of peaks, perform faster analysis, sharper, and higher peaks [14].

\section{UHPLC-MS/MS detection}

To detect and find out the amount of analyte, the mass spectrometry (MS) was widely used because of its selectively (Watson and Sparkman 2007; Chiu and Muddiman 2008). UHPLC-MS/MS method detection is considered as a method of choice for estimation of drugs in bulk and pharmaceutical formulations and their metabolites in biological fluids. In literature, there are several methods reported for analysis of drugs using UHPLC-MS/MS. In all ionization techniques, electrospray ionization (ESI) and atmospheric chemical ionization (APCI) ion source were extensively used [15]. Among all kinds of mass analyzers viz quadrupole, ion trap, and time of flight, the triple quadrupole was the most preferred one. The several mobile phases were used in UHPLC-MS/MS that includes many solvents such as water, $\mathrm{ACN}$ or $\mathrm{MeOH}$, acetic acid, $0.1 \%$ formic acid, ammonium hydroxide/ammonia solution, and ammonium acetate (10 mM).

Mass spectrophotometer prominently consists of an ion source to construct gas phase ions and mass analyzers to separate these ions according to their mass to charge ratio; further, a detector to count the ions for every $\mathrm{m} / \mathrm{z}$ ratios. The $\mathrm{PC}$ will change over the information from the analyzer and detector to a mass spectrum $[16,17]$. The choice of detector is based on the necessary detection sensitivity and it is additionally controlled by other clear necessity; for example, the thermal, chemical, and required stability and the amount of space available. Ideal properties for detectors are high intensification, fast time analysis, low noise, high collection efficiency, minimal effort, narrow distribution of responses, and long life [18]. The MS-MS detectors are more advantageous over the other detectors with respective to the higher sensitivity to detect very small quantity, high selectivity to notify molecules apart in a mixture, and high time resolution and long lifetime. There are different detectors which are used in mass spectrophotometer such as electron multiplier, Faraday cup electrode, and photomultiplier. Electron multiplier is based on that the ion or electrons strikes on the first dynode, resulting in the emission of several electrons. These secondary electrons are then attracted to the second dynode, where 


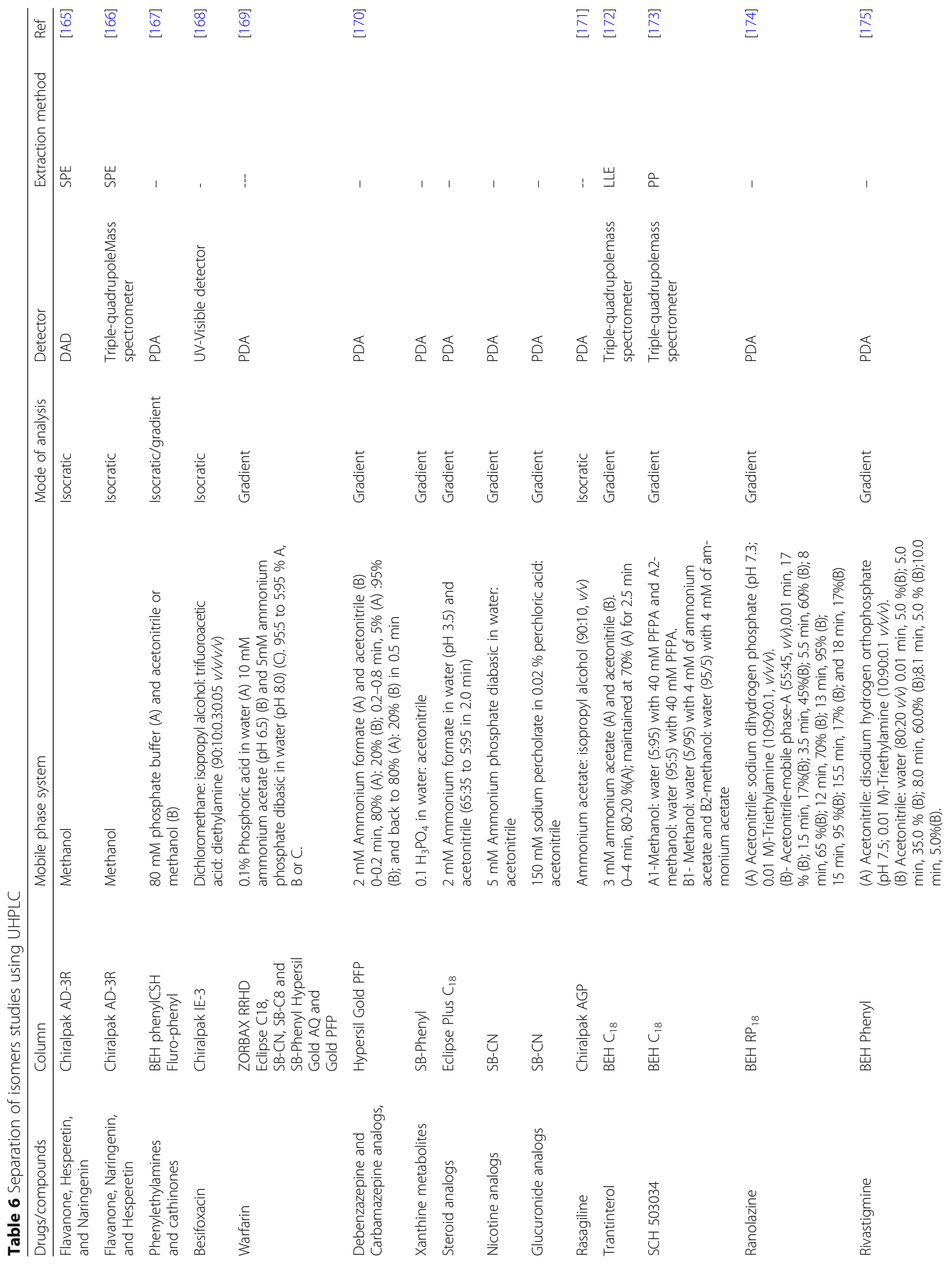




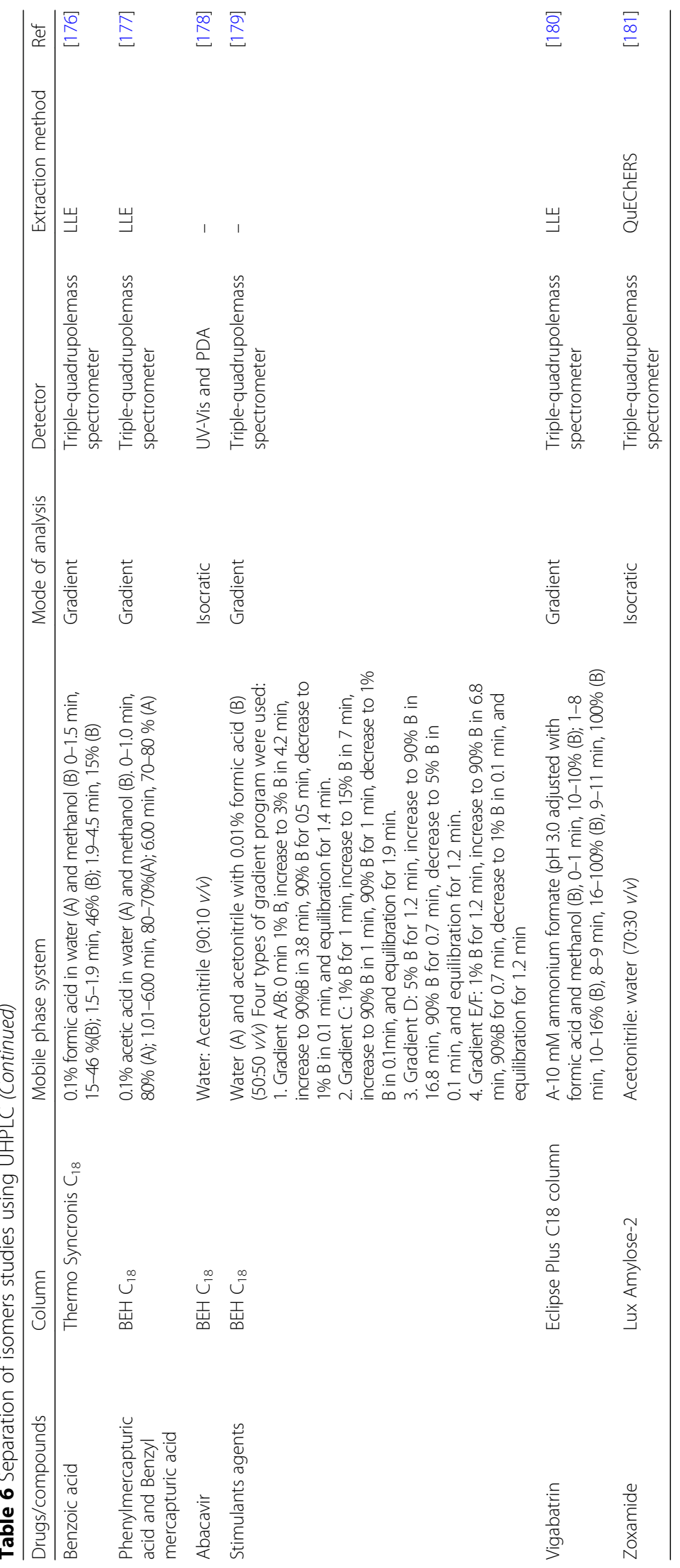


every electron creates a few more electrons, and likewise the electrons are produced. The electron multiplier offers several advantages over the other detectors like low noise, high sensitivity, and typical gain of 106 and total life of electron multiplier 1-2 years. Faraday cup electrode is also known as cylinder electrode. The basic principle behind cylinder electrode is that the incident ion strikes the dynode surface which emits electrons and induces a current which is amplified and recorded. The dynode electrons which are used in faraday cup are made up of secondary emitting material like $\mathrm{CsSb}, \mathrm{GaP}$, or $\mathrm{BeO}$. The cylinder electrode is very robust and it is generally used to isotope analysis and isotope-ratio mass spectrometry (IRMS). The photomultiplier are currently presumably the most widely recognized in mass spectrophotometer and it's also known as scintillation counter. The basic principle of scintillation counter or photomultiplier is that the ions at first strike a dynode which outcome in electron emission. These electrons then strike a phosphorous screen which thusly discharges a burst of photons. The photons then pass into the multiplier where amplification occurs in a cascade fashion. The main advantage of using photons is that the multiplier can be kept sealed in a vacuum preventing contamination and greatly extending the lifetime of the detector $[16,19]$.

\section{Present perspective on UHPLC-MS/MS methods}

The magnitude of the topic on a UHPLC-MS/MS can be learnt from the review articles published on the topics; to our knowledge, more than 11 [20-30] review articles on various facets of UHPLC-MS/MS have been published by different authors. The brief summary of review articles published in different journals on the topic "UHPLC-MS/MS" is depicted in Table 2.

\section{Application of UHPLC-MS/MS \\ Bio-analytical method/metabolite studies}

The sensitivity and selectivity of UHPLC at low detection levels produces precise dependable information that can be utilized for a wide range of purposes, including pharmacokinetics study, toxicity, and bioequivalence studies as the quantification of a medicinally active agent in biological samples is a crucial part of the development program of a bioanalytical method. The sample preparation techniques gained more significance in bioanalytical methods. UHPLC-MS has vital importance in metabolomics and proteomics [31]. A variety of sample preparation techniques have been applied in a bioanalytical method such as protein precipitation, liquid-liquid extraction, and solid-phase extraction [32]. Among these, the most widely used are protein precipitation and liquid-liquid extraction followed by solid-phase extraction which are used in different category such as antibiotic [33-40], anticancer [36, 41-45, 46-62], antiviral [63-67], antifungal [68-72], cardiovascular [73-86], analgesic [87-93], steroid [94, 95], NSAID [96-106], diabetes [107-110], antidepressant [111-114], antiepileptic [115-119], CNS [120, 121], proton pump inhibitor [122], anti-tubercular [123], vitamin [124, 125], immunosuppressant [126-128], anticoagulant $[129,130]$, expectorant [102], and multicomponent analysis of drug [131-145]. The simplest is protein precipitation by acetonitrile and centrifugation prior to analysis. The liquid-liquid extraction by ter-butyl methyl ether, chloroform, ethyl acetate, ethyl ether, etc., and solid-phase extraction techniques, disks, or cartridges are used to extract the sample by using methanol, formic acid, water, etc [146]. Bioanalytical studies using UHPLC-MS/MS is summarized in Table 3 and Fig. 2.

\section{Stability-indicating method using UHPLC-MS/MS}

It is performed at the preliminary stage in the process of drug development [7]. The research conditions force the drug compounds to degrade under tremendous conditions such as acid and base hydrolysis, peroxide oxidation, photo-oxidation, and thermal stability to identify the resultant degradation products. Stability indicating method using UHPLC-MS/MS is included in Table 4 [147-153]

\section{Impurity profile of drug using UHPLC/MS/MS}

For the medicine development and formulation process, profiling, detection, and evaluation of drug substances and their contamination in crude materials and finishing yield testing is an essential part which is summarized in Table 5 [3] [154-163].

\section{UHPLC in separation of isomers}

Chirality may influence biological activity; so, there is a necessity for the enantioseparation or diasterioseparation of these compounds. Therefore, sequentially to further examine the mechanisms of action of the enantiomers or diastereomers, it is necessary to understand which compounds are present at the site of action. Therefore, there is an increased demand for sensitive analytical methods to quantify and evaluate the chirality of metabolites present in biological fluids [96]. UHPLC is an incredible tool for the present rehearsing chromatographer, as it can essentially expand the output of a chromatographic separation. What is more, the more extensive scope of usable stream rates makes rapid partitions conceivable. Up till now, various UHPLC columns were employed for separation of structural analogs or for separation of isomers. These UHPLC columns are flexible column with excellent chemical durability and are suitable for quick analysis of samples containing hydrophobic compounds that are strongly retained 
in columns or samples containing compounds with large differences in hydrophobicity. In addition, its high bonding density consent for excellent separation of compounds with minute structural differences. Furthermore, these UHPLC columns are used for a wide range of application areas such as measuring the optical purity wand purification of chiral materials [164]. The separations of isomers using UHPLC are summarized in Table 6.

\section{Future direction}

In the last decade, literature survey shows that several drugs and metabolites were separated, from their impurities and degradation product by implementing UHPLCMS/MS technique. For separation or extraction of analytes or drugs and metabolites from the biological fluid with the help of organic solvents, but there are many problems associated with those organic solvents such as toxic nature, injurious to the environment, and dangerous. To overcome these problems, the green solvents are the choice for extraction of analytes. In the future, the more prominent result is also obtained with the help of green solvents because advantage green solvents are their high viscosity, high thermal stability, and low vapor pressure. They are also highly reusable and therefore considered efficient compared to organic solvents. In this survey, the column generally used is $\mathrm{BEH} \mathrm{C18.} \mathrm{The}$ green solvents with the help of increases; highthroughput, sensitivity, and resolution of drugs analysis and identify structures of compounds. Nonetheless, steady up gradation of UHPLC-MS/MS techniques besides data-handling routines are still obligatory for data preprocessing, statistical analysis, biomarker recognition impurity, and degrades products.

\section{Discussion and conclusion}

The presented review article gives a perspective on UHPLC-MS/MS in drug substance and medicine product. The current review article collects a simplified, fast, and selective UHPLC-MS/MS methods which were developed for the determination of drug in bulk and also in plasma. UHPLC-MS/MS technique holds out a very promising system for isolation, characterization, and identification of degradation products and impurities. This knowledge can create abundant information about drugs and guidance for its storage, increasing tools for quality control, and safer treatments.

\section{Abbreviations}

BEH: Ethylene-bridged hybrid; CSH: Charged surface hybrid; HETP: Height equivalent of theoretical plate; HILIC: Hydrophilic interaction chromatography; HPLC: High-performance liquid chromatography; HSS: High strength silica; IRMS: Isotope-ratio mass spectrometry; LC: Liquid chromatography; LLE: Liquid-liquid extraction; MPa: Megapascal; MS: Mass spectroscopy; NSAID: Nonsteroidal anti-inflammatory drug; PP: Protein precipitation; Psi: Per square inch; PST: Peptide separation technology; QuEChERS: Quick, easy, cheap, effective, rugged, and safe; RP: Reverse phase;
SB: Selectivity for bases; SPE: Solid-phase extraction; UHPLC: Ultra highperformance liquid chromatography; UPLC-MS/MS: Ultra performance liquid chromatography-mass spectroscopy

\section{Acknowledgement}

The authors are thankful to Principal of R.C. Patel Institute of Pharmaceutical Education and Research Shirpur, Dist: Dhule (MS) 425405 for providing necessary library facilities.

\section{Ethic approval and consent to participate} Not applicable

\section{Author's contribution}

RHR and ASP carried out literature review on applications of UHPLC-MS/MS in drug analysis. AAS and SRC organized a preliminary draft of the article. All authors read and approved the final manuscript.

\section{Funding}

Not applicable.

\section{Availability of data and materials}

Not applicable.

\section{Consent for publication}

Not applicable

\section{Competing interests}

The authors declare that they have no competing interests.

Received: 24 July 2019 Accepted: 9 September 2019

Published online: 31 October 2019

\section{References}

1. Walter TH, Andrews RW (2014) Recent innovations in UHPLC columns and instrumentation. Trends Anal Chem 63:14-20. https://doi.org/10.1016/j.trac. 2014.07.016

2. Singh S, Prasad L, Kumar V, Roy S, Patnaik SK (2016) Ultra performance liquid chromatography: high throughput analysis over high performance liquid chromatography. Int J Eng Allied Sci 2:19-25

3. Samatha Y, Srividya A, Ajitha A, Rao VUM (2015) Ultra performance liquid chromatography (UPLC). World J Pharm Pharm Sci 8:356-367

4. Swartz ME (2005) UPLC: an introduction and review. J Liq Chromatogr Relat Technol 28:1253-1263. https://doi.org/10.1081/JLC-200053046

5. Ht Quantitative Analysis for a drug mixture by LC/MS/MS: UPLC-MS/MS and HPLC-MS/MS Compared (2005) water. http://www.water.com.

6. Novakova L, Matysova L, Solich P (2006) Advantages of application of UPLC in pharmaceutical analysis. Talanta 68:908-918. https://doi.org/10.1016/j. talanta.2005.06.035

7. Chawla G, Ranjan C (2016) Principle, instrumentation, and applications of UPLC: A novel technique of liquid chromatography. Open Chem J 3:1-16. https://doi.org/10.2174/1874842201603010001

8. Phalke P, Kavade S (2013) Review on hyphenated techniques. Int J Chem Stud1:157-165

9. UPLC columns and consumables. https://www.waters.com//UPLCColumns 2014.

10. Acquity UPLC column by water. https://www.waters.com/waters/ acquitycolumns 2015.

11. Acquity UPLC column solution. https://www.waters.com//UPLCColumns 2009.

12. Acquity UPLC columns by waters. https://www.waters.com 2008.

13. Roge AB, Firke SN, Dhane RM, Gunjkar VJ, Vadvalkar SM (2011) Novel achievement of HPLC: UPLC. Int JPharm Tech Res 3:1423-1429

14. Narwate BM, Ghule PJ, Ghule AV, Darandale AS, Wagh JG (2014) Ultra performance liquid chromatography: A new resolution in chromatography. Int J Pharm Drug Anal 2:25-34

15. Principles and applications of LC-MS/ (2012) MS for the quantitative bioanalysis of analytes in various biological samples. In: tandem mass spectrometry-applications and principles. http://www.intechopen.com

16. Khatri N, Gupta A, Taneja R, Bilandi A, Beniwal P (2012) A review on mass spectrophotometry detectors. Int Res J Pharm 3:33-42 
17. De Hoffmann E (2000) Mass spectrometry. Kirk-Othmer Encyclopedia of Chemical Technology.

18. Mass Spectrometry Detectors. https://www.colorado.edu/mass spectrophotmetry detector/. 2009.

19. Mass Spectrometry detectors. http://www.chm.bris.ac.uk/ms/detectors. Accessed 28 Nov 2018

20. Higashi T, Shimada K, Toyooka T (2010) Advances in determination of vitamin $\mathrm{D}$ related compounds in biological samples using liquid chromatography-mass spectrometry: a review. JChromatogr B 878:16541661. https://doi.org/10.1016/j.jchromb.2009.11.026

21. Roux A, Lison D, Junot C, Heilier JF (2011) Applications of liquid chromatography coupled to mass spectrometry-based metabolomics in clinical chemistry and toxicology. Clin Biochem 44:119-135. https://doi.org/ 10.1016/j.clinbiochem.2010.08.016

22. Zoerner AA, Gutzki FM, Batkai S, May M, Rakers C, Engeli S, Jordan J, Tsikas D (2011) Quantification of endocannabinoids in biological systems by chromatography and mass spectrometry: a comprehensive review from an analytical and biological perspective. Biochim Biophys Acta 1811:706-723. https://doi.org/10.1016/j.bbalip.2011.08.004

23. Gosetti F, Mazzucco E, Gennaro MC, Marengo E (2013) Ultra high performance liquid chromatography tandem mass spectrometry determination and profiling of prohibited steroids in human biological matrices. A review. J Chromatogr B 927:22-36. https://doi.org/10.1016/j. jchromb.2012.12.003

24. Bantscheff M, Lemeer S, Savitski MM, Kuster B (2012) Quantitative mass spectrometry in proteomics: critical review update from 2007 to the present. Anal Bioanal Chem 404:939-965. https://doi.org/10.1007/s00216012-6203-4

25. Viant MR, Sommer U (2013) Mass spectrometry based environmental metabolomics: a primer and review. Metabolomics 9:144-158. https://doi. org/10.1007/s11306-012-0412-x

26. Motilva MJ, Serra A, Macia A (2013) Analysis of food polyphenols by ultra high-performance liquid chromatography coupled to mass spectrometry: an overview. J Chromatogr A 1292:66-82. https://doi.org/10.1016/j.chroma. 2013.01.012

27. Pratima NA, Shraddha B, Zibran S (2013) Review of ultra performance liquid chromatography and its applications. Int J Res Pharm Sci 3:1-42

28. Gouveia MJ, Brindley PJ, Santos LL, da Costa JMC, Gomes P, Vale N (2013) Mass spectrometry techniques in the survey of steroid metabolites as potential disease biomarkers: a review. Metabolism 62:1206-1217. https:// doi.org/10.1016/j.metabol.2013.04.003

29. Kailemia MJ, Ruhaak LR, Lebrilla CB, Amster IJ (2013) Oligosaccharide analysis by mass spectrometry: a review of recent developments. Anal Chem 86:196-212. https://doi.org/10.1021/ac403969n

30. Kortz L, Dorow J, Ceglarek U (2014) Liquid chromatography-tandem mass spectrometry for the analysis of eicosanoids and related lipids in human biological matrices: a review. J Chromatogr B 964:1-11. https://doi.org/10. 1016/j.jchromb.2014.01.046

31. Desai TK, Mahajan AA, Thaker A (2012) Ultra performance liquid chromatography: a step ahead to HPLC. Int J Pharm Res Rev 2:61-68

32. Kole PL, Venkatesh G, Kotecha J, Sheshala R (2011) Recent advances in sample preparation techniques for effective bioanalytical methods. Biomed Chromatogr 25(1-2):199-217. https://doi.org/10.1002/bmc.1560

33. Carlier M, Stove V, Roberts JA, Van de VE, De WJJ, Verstraete AG (2012) Quantification of seven $\beta$-lactam antibiotics and two $\beta$-lactamase inhibitors in human plasma using a validated UPLC-MS/MS method. Int J Antimicrob Agents 40:416-422. https://doi.org/10.1016/j.jjantimicag.2012.06.022

34. Zhao L, Zhao Y, Li Q, Chen X, Xiao F, He B, Wang J, Bi K (2012) A fast, sensitive, and high throughput method for the determination of cefuroxime lysine in dog plasma by UPLC-MS/MS. Talanta 89:84-90. https://doi.org/10. 1016/j.jijantimicag.2012.06.022

35. Wang YJ, Wu YT, Lin JY, Chu CH, Huang HY, Wang YC, Chen JK, Yang CS (2012) Rapid quantitative analysis of clarithromycin in rat plasma by UPLCMS/MS after intravenous injection of the clarithromycin-loaded ultrafine PLGA nanoparticles. J Chromatogr B 895:178-181. https://doi.org/10.1016/j. jchromb.2012.03.022

36. Oufir M, Sampath C, Butterweck V, Hamburger M (2012) Development and full validation of an UPLC-MS/MS method for the determination of an antiallergic indolinone derivative in rat plasma, and application to a preliminary pharmacokinetic study. J Chromatogr B 902:27-34. https://doi.org/10.1016/j. jchromb.2012.06.009
37. Marca GL, Giocaliere E, Villanelli F, Malvagia S, Funghini S, Ombrone D, Filippi L, Gaudio MD, Martino MD, Galli L (2012) Development of an UPLCMS/MS method for the determination of antibioticertapenem on dried blood spots. J Pharm Biomed Anal 61:108-113. https://doi.org/10.1016/j. jpba.2011.12.018

38. Chahbouni A, Dungen FAVD, Vos RM, den Burger JC, Sinjewel A, Wilhelm AJ, Veldkamp Al, Swart EL, van Weissenbruch MM (2015) An UPLC-MS detection method for the quantification of five antibiotics in human plasma. Bioanalysis 7:2321-2329. https://doi.org/10.4155/bio.15.121

39. Wang XS, Sun JC, Yang RN, Ren J, Liang S, Sun M, Wang YF, Gao SG (2014) Determination of cephalomannine in rat plasma by gradient elution UPLCMS/MS method. J Chromatogr B 963:70-74. https://doi.org/10.1016/j. jchromb.2014.05.045

40. Yu HC, Pan CW, Xie QP, Zheng Y, Hu YZ, Lin YM (2016) Simultaneous determination of tedizolid and linezolid in rat plasma by ultra performance liquid chromatography tandem mass spectrometry and its application to a pharmacokinetic study. J Chromatogr B 1011:94-98. https://doi.org/10.1016/ j.jchromb.2015.12.056

41. Li Y, Sun Y, Du F, Yuan K, Li C (2008) Pulse gradient, large-volume injection, high-throughput ultra-performance liquid chromatographic/tandem mass spectrometry bioanalysis for measurement of plasma amrubicin and its metabolite amrubicinol. J Chromatogr A 1193:109-116. https://doi.org/10. 1016/j.chroma.2008.04.014

42. Chen Y, Zhang S, Chen D, Zhou M, Zheng J, Xiang Z (2015) An UPLC-MS/ MS method for determination of solasonine in rat plasma and its application of a pharmacokinetic and bioavailability study. J Chromatogr B 985:1-5. https://doi.org/10.1016/j.jchromb.2015.01.017

43. Wang X, Wang S, Ma J, Ye T, Lu M, Fan M, Deng M, Hu L, Gao Z (2015) Pharmacokinetics in rats and tissue distribution in mouse of berberrubine by UPLC-MS/MS. J Pharm Biomed Anal 115:368-374. https://doi.org/10. 1016/j.jpba.2015.07.031

44. Iqbal M, Ezzeldin E, Al-Rashood KA, Shakeel F (2015) A validated UPLC-MS/ MS assay using negative ionization mode for high-throughput determination of pomalidomide in rat plasma. J Chromatogr B 983:76-82. https://doi.org/10.1016/j.jchromb.2014.12.036

45. Du P, Li N, Wang H, Yang S, Song Y, Han X, Shi Y (2013) Development and validation of a rapid and sensitive UPLC-MS/MS method for determination of total docetaxel from a lipid microsphere formulation in human plasma. J Chromatogr B 926:101-107. https://doi.org/10.1016/j.jchromb.2013.02.006

46. Iqbal M, Wani TA, Khalil NY, Darwish IA (2013) Development and validation of ultra-performance liquid chromatographic method with tandem mass spectrometry for determination of lenalidomide in rabbit and human plasma. Chem Cent J 7:1-9. https://doi.org/10.1186/1752-153X-7-7

47. Zhang SQ, Chen GH (2008) Determination of paclitaxel in human plasma by UPLC-MS-MS. J Chromatogr Sci 46:220-224. https://doi.org/10.1093/ chromsci/46.3.220

48. Goldwirt L, Lemaitre F, Zahr N, Farinotti R, Fernandez C (2012) A new UPLCMS/MS method for the determination of irinotecan and 7-ethyl-10hydroxycamptothecin (SN-38) in mice: application to plasma and brain pharmacokinetics. J Pharm Biomed Anal 66:325-333. https://doi.org/10. 1016/j.jpba.2012.04.003

49. Ju P, Liu Z, Jiang $Y$, Zhao $S$, Zhang L, Zhang $Y$, Gu L, Tang $X$, Bi K, Chen $X$ (2015) Determination of a novel anticancer c-Met inhibitor LS-177 in rat plasma and tissues with a validated UPLC-MS/MS method: application to pharmacokinetics and tissue distribution study. Biomed Chromatogr 29: 1103-1111. https://doi.org/10.1002/bmc.3397

50. Lin H, Zhao Y, Men L, Yang M, Liu SY, Wang P, Tang X, Yu Z (2015) Development of a rapid and sensitive UPLC-MS/MS assay for the determination of TM-2 in beagle dog plasma and its application to a pharmacokinetic study. Biomed Chromatogr 29:110-114. https://doi.org/10. 1002/bmc.3246

51. Haandel LV, Becker ML, Williams TD, Leeder JS, Stobaugh JF (2011) Measurement of methotrexate polyglutamates in human erythrocytes by ion-pair UPLC-MS/MS. Bioanalysis 3:2783-2796. https://doi.org/10. 4155/bio.11.288

52. Hubicka U, Żmudzki P, Talik P, Żuromska WB, Krzek J (2013) Photodegradation assessment of ciprofloxacin, moxifloxacin, norfloxacin and ofloxacin in the presence of excipients from tablets by UPLC-MS/MS and DSC. Chem Cent J7:133. https://doi.org/10.4155/bio.11.288

53. Goldwirt L, Zahr N, Farinotti R, Fernandez C (2013) Development of a new UPLC-MSMS method for the determination of temozolomide in mice: 
application to plasma pharmacokinetics and brain distribution study. Biomed Chromatogr 27:889-893. https://doi.org/10.1002/bmc.2877

54. Wang S, Wu H, Geng P, Lin Y, Liu Z, Zhang L, Ma L, Zhou Y, Wang X, Wen C (2016) Pharmacokinetic study of dendrobine in rat plasma by ultraperformance liquid chromatography tandem mass spectrometry. Biomed Chromatogr 30:1145-1149. https://doi.org/10.1002/bmc.3641

55. Li N, Han X, Du P, Song Y, Hu X, Yang S, Shi Y (2014) Development and validation of a UPLC-MS/MS assay for the quantification of simotinib in human plasma. Anal Bioanal Chem 406:1799-1805. https://doi.org/10.1007/ s00216-013-7570-1

56. Lin D, Qiao LM, Zhang N, Liu Y, Liu XS (2016) Simultaneous determination of nintedanib and its metabolite by UPLC-MS/MS in rat plasma and its application to a pharmacokinetic study. J Pharm Biomed Anal 117:173-177. https://doi.org/10.1016/j.jpba.2015.08.024

57. $C A O G, Z H A N G$ Q, YANG X (2015) Determination of Letrozole in rat plasma by UPLC-MS/MS and its application to a pharmacokinetic study. Lat Am J Pharm 34:45-50

58. Zhao AQ, Zhao JH, Zhang SQ, Pan YY, Huo XL (2016) Determination of parthenolide in rat plasma by UPLC-MS/MS and its application to a pharmacokinetic study. J Pharm Biomed Anal 119:99-103. https://doi.org/10. 1016/j.jpba.2015.11.039

59. Dahmane E, Mercier T, Zanolari B, Cruchon S, Guignard N, Buclin T, Leyvraz S, Zaman K, Csajka C, Decosterd LA (2010) An ultra performance liquid chromatography-tandem MS assay for tamoxifen metabolites profiling in plasma: first evidence of 4'-hydroxylated metabolites in breast cancer patients. J Chromatogr B 878:3402-3414. https://doi.org/10.1016/j.jchromb.2010.10.027

60. Yang F, Wang H, Hu P, Jiang J (2014) Validation of an UPLC-MS-MS method for quantitative analysis of vincristine in human urine after intravenous administration of vincristine sulfate liposome injection. J Chromatogr Sci 53: 974-978. https://doi.org/10.1093/chromsci/bmu164

61. Yang S, Qin F, Wang D, Li N, Li F, Xiong Z (2012) Determination of palonosetron in human plasma by ultra performance liquid chromatographytandem mass spectrometry and its application to a pharmacokinetic study. J Pharm Biomed Anal 57:13-18. https://doi.org/10.1016/j.jpba.2011.08.038

62. Zhang WM, Li RF, Qiu JF, Zhang ZY, Wang HB, Bian L, Lei JH (2015) Determination of kurarinone in rat plasma by UPLC-MS/MS. J Chromatogr B 986:31-34. https://doi.org/10.1016/j.jchromb.2015.02.005

63. Liu H, Xu H, Song W, Zhang Y, Yu S, Huang X (2016) Validated UPLC/MS/MS assay for quantitative bioanalysis of elbasvir in rat plasma and application to pharmacokinetic study. J Chromatogr B 1015:150-156. https://doi.org/10. 1016/j.jchromb.2016.02.025

64. Rezk MR, Bendas ER, Basalious EB, Karim IA (2016) Development and validation of sensitive and rapid UPLC-MS/MS method for quantitative determination of daclatasvir in human plasma: application to a bioequivalence study. J Pharm Biomed Anal 128:61-66. https://doi.org/10. 1016/j.jpba.2016.05.016

65. Shi X, Zhu D, Lou J, Zhu B, Hu AR, Gan D (2015) Evaluation of a rapid method for the simultaneous quantification of ribavirin, sofosbuvir and its metabolite in rat plasma by UPLC-MS/MS. J Chromatogr B 1002:353-357. https://doi.org/10.1016/j.jchromb.2015.08.038

66. Mishra T, Shrivastav PS (2014) Validation of simultaneous quantitative method of HIV protease inhibitors atazanavir, darunavir and ritonavir in human plasma by UPLC-MS/MS. Sci World J:1-12. https://doi.org/10.1155/2014/482693

67. Li TX, Chu CS, Zhu JY, Yang TY, Zhang J, Hu YT, Yang XH (2016) A rapid UPLC-MS/MS method for the determination of oleanolic acid in rat plasma and liver tissue: application to plasma and liver pharmacokinetics. Biomed Chromatogr 30:520-527. https://doi.org/10.1002/bmc.3577

68. Jiménez GM, Contreras-Zavala L, Maggi-Castellanos M, Ángeles-Moreno AP, García-González A (2012) Development of a method by UPLC-MS/MS for the quantification of tizoxanide in human plasma and its pharmacokinetic application. Bioanalysis 4:909-917. https://doi.org/10.4155/bio.12.41

69. Wang Z, Huang CK, Sun W, Xiao C, Wang ZS (2015) UPLC-MS/MS determination of voriconazole in human plasma and its application to a pharmacokinetic study. Biomed Chromatogr 29:188-193. https://doi.org/10.1002/bmc.3257

70. Al-Quadeib BT, Radwan MA, Siller L, Mutch E, Horrocks B, Wright M, Alshaer A (2014) Therapeutic monitoring of amphotericin B in Saudi ICU patients using UPLC MS/MS assay. Biomed Chromatogr 28:1652-1659. https://doi. org/10.1002/bmc.3198

71. Decosterd LA, Rochat B, Pesse B, Mercier T, Tissot F, Widmer N, Bille J, Calandra T, Zanolari B, Marchetti O (2010) Multiplex ultra-performance liquid chromatography-tandem mass spectrometry method for simultaneous quantification in human plasma of fluconazole, itraconazole, hydroxyitraconazole, posaconazole, voriconazole, voriconazole-N-oxide, anidulafungin, and caspofungin. Antimicrob Agents Chemother 54:53035315. https://doi.org/10.1128/AAC.00404-10

72. Rochat B, Pascual A, Pesse B, Lamoth F, Sanglard D, Decosterd LA, Bille J, Marchetti O (2010) Ultra-performance liquid chromatography mass spectrometry and sensitive bioassay methods for quantification of posaconazole plasma concentrations after oral dosing. Antimicrob Agents Chemother 54:5074-5081. https://doi.org/10.1128/AAC.00022-10

73. Abdelbary G, Nebsen M (2013) Application of a novel UPLC-MS/MS method for the pharmacokinetic/bioequivalence determination of atorvastatin and ezetimibe in human plasma. J Pharm Res 7:24-32. https://doi.org/10.1016/j. jopr.2013.01.010

74. Patel DP, Sharma P, Sanyal M, Singhal P, Shrivastav PS (2013) UPLC-MS/MS assay for the simultaneous quantification of carvedilol and its active metabolite 4'-hydroxyphenyl carvedilol in human plasma to support a bioequivalence study in healthy volunteers. Biomed Chromatogr 27:974986. https://doi.org/10.1002/bmc.2889

75. Zoerner AA, Schroeder C, Kayacelebi AA, Suchy MT, Gutzki FM, Stichtenoth DO, Tank J, Jordan J, Tsikas D (2013) A validated, rapid UPLC-MS/MS method for simultaneous ivabradine, reboxetine, and metoprolol analysis in human plasma and its application to clinical trial samples. J Chromatogr B 927:105-111. https://doi.org/10.1016/j.jchromb.2013.01.016

76. Pidpruzhnykov YV, Sabko EV, lurchenko W, Zupanets IA (2012) UPLC-MS/MS method for bioequivalence study of oral drugs of Meldonium. Biomed Chromatogr 26:599-605. https://doi.org/10.1002/bmc.1703

77. Singh B, Lokhandae RS, Dwivedi A, Sharma S, Dubey N (2014) Improved simultaneous quantitation of candesartan and hydrochlorthiazide in human plasma by UPLC-MS/MS and its application in bioequivalence studies. J Pharm Anal 4:144-152

78. Al-Dirbashi OY, Aboul-Enein HY, Jacob M, Al-Qahtani K, Rashed MS (2016) UPLC-MS/MS determination of doxazosine in human plasma. Anal Bioanal Chem 38:1439-1443. https://doi.org/10.1007/s00216-006-0553-8

79. Kalovidouris M, Michalea S, Robola N, Koutsopoulou M, Panderi I (2006) Ultra-performance liquid chromatography/tandem mass spectrometry method for the determination of lercanidipine in human plasma. Rapid Commun Mass Spectrom 20:2939-2946

80. Ebeid MW, Elkady EF, El-Zaher AA, El-Bagary RI, Patonay G (2015) Simultaneous Determination of Aliskiren Hemifumarate, Amlodipine Besylate and Hydrochlorothiazide in Spiked Human Plasma Using UPLC-MS/MS. J Chromatogr Sci 53:178-1184. https://doi.org/10.1093/chromsci/bmu213

81. Wani TA, Zargar S (2015) New ultra-performance liquid chromatographytandem mass spectrometry method for the determination of irbesartan in human plasma. J Food Drug Anal 23:569-576. https://doi.org/10.1016/j.jfda. 2015.02.008

82. Rezk MR, Badr KA (2014) Development, optimization and validation of a highly sensitive UPLC-ESI-MS/MS method for simultaneous quantification of amlodipine, benazeprile and benazeprilat in human plasma: application to a bioequivalence study. J Pharm Biomed Anal 98:1-8. https://doi.org/10.1016/ j.jpba.2014.05.005

83. Prajapati ST, Patel PK, Chauhan VB, Patel CN, Patel M (2011) Development and validation of the liquid chromatography-tandem mass spectrometry method for quantitative estimation of candesartan from human plasma. Pharm Methods 2:130-134. https://doi.org/10.4103/2229-4708.84460

84. Favreto WAJ, Pugens Pinto AM, Manfio JL, Fiametti KG, Percio MF, Santos MBD (2012) Development and validation of a UPLC-ESI-MS/MS method for the determination of $\mathrm{N}$-butylscopolamine in human plasma: application to a bioequivalence study. Drug Test Anal 4:215-221. https://doi.org/10.1002/dta.40

85. Bae SK, Kang MJ, Yeo CW, Kim MJ, Shon JH, Liu KH, Shin JG (2008) Simultaneous determination of udenafil and its active metabolite, DA-8164, in human plasma and urine using ultra-performance liquid chromatographytandem mass spectrometry: application to a pharmacokinetic study. Biomed Chromatogr 22:939-946. https://doi.org/10.1002/bmc.1011

86. Lin X, Zhang Y, Cui Y, Wang L, Wang J, Tang X (2009) Determination of alprostadil in rat plasma by ultra performance liquid chromatographyelectrospray ionization-tandem mass spectrometry after intravenous administration. J Pharm Biomed Anal 49:983-988. https://doi.org/10.1016/j. jpba.2009.01.019

87. Kumbhar AB, Galgatte UC, Warkad S, Santhakumari B (2013) Development and validation of a sensitive bioanalytical method for the determination of sumatriptan in rat plasma by UPLC-MS. Int J Pharm Pharm Sci 5:78-82 
88. Liang L, Wan S, Xiao J, Zhang J, Gu M (2011) Rapid UPLC-MS/MS method for the determination of sufentanil in human plasma and its application in target-controlled infusion system. J Pharm Biomed Anal 54:838-844. https:// doi.org/10.1016/j.jpba.2010.11.016

89. Vuppala K, Boddu SP, Furr EB, McCurdy (2011) A Simple, sensitive, highthroughput method for the quantification of mitragynine in rat plasma using UPLC-MS and its application to an intravenous pharmacokinetic study. Chromatographia 74:703-710. https://doi.org/10.1007/s10337-011-2128-x

90. Hillewaert V, Pusecker $K$, Sips L, Verhaeghe T, Vries RD, Langhans M, Terlinden R, Timmerman P (2015) Determination of tapentadol and tapentadol-O-glucuronide in human serum samples by UPLC-MS/MS. J Chromatogr B 981:40-47. https://doi.org/10.1016/j.jchromb.2014.12.013

91. Inoue K, Sakamoto T, Fujita Y, Yoshizawa S, Tomita M, Min JZK, Todoroki K, Sobue T, Toyo'oka (2013) Development of a stable isotope dilution UPLCMS/MS method for quantification of dexmedetomidine in a small amount of human plasma. Biomed Chromatogr 27: 853-858. doi:https://doi.org/10. 1002/bmc.2870

92. Huang PW, Liu HT, Hsiong CH, Pao LH, Lu CC, Ho ST, Hu OYP (2013) Simultaneous determination of nalbuphine and its prodrugsebacolydinalbuphine ester in human plasma by ultra-performance liquid chromatography-tandem mass spectrometry and its application to pharmacokinetic study in humans. Biomed Chromatogr 27:831-837. https://doi.org/10.1002/bmc.2867

93. Lüthi G, Blangy V, Eap CB, Ansermot N (2013) Buprenorphine and norbuprenorphine quantification in human plasma by simple protein precipitation and ultra-high performance liquid chromatography tandem mass spectrometry. J Pharm Biomed Anal 77:1-8. https://doi.org/10.1016/j. jpba.2012.12.023

94. Licea-Perez H, Wang S, Szapacs ME, Yang E (2008) Development of a highly sensitive and selective UPLC/MS/MS method for the simultaneous determination of testosterone and $5 \mathrm{a}$-dihydrotestosterone in human serum to support testosterone replacement therapy for hypogonadism. Steroids 73:60-610. https://doi.org/10.1016/j.steroids.2008.01.018

95. Liu H, Yang M, Wu P, Guan J, Men L, Lin H, Tang X, Zhao Y, Yu Z (2015) Simultaneous determination of triamcinolone acetonidepalmitate and triamcinolone acetonide in beagle dog plasma by UPLC-MS/MS and its application to a long-term pharmacokinetic study of triamcinolone acetonidepalmitate lipid emulsion injection. J Pharm Biomed Anal 104:105111. https://doi.org/10.1016/j.jpba.2014.11.028

96. Leveques A, Actis-Goretta L, Rein MJ, Williamson G, Dionisi F, Giuffrida F (2012) UPLC-MS/MS quantification of total hesperetin and hesperetin enantiomers in biological matrices. J Pharm Biomed Anal 57:1-6. https://doi. org/10.1016/j.jpba.2014.11.028

97. Wong KC, Law MC, Wong MS, Chan TH (2014) Development of a UPLC-MS/ MS bioanalytical method for the pharmacokinetic study of (-)-epiafzelechin, a flavan-3-ol with osteoprotective activity, in C57BL/6J mice. J Chromatogr B 967:162-167. https://doi.org/10.1016/j.jchromb.2014.07.028

98. Mano Y, Ishii T, Hotta K, Kusano K (2015) Validation of a UPLC-MS/MS method for the simultaneous determination of E6005, a phosphodiesterase 4 inhibitor, and its metabolite in human plasma. J Chromatogr B 998:31-39. https://doi.org/10.1016/j.jchromb.2015.06.023

99. Li X, Xiong Z, Lu S, Zhang Y, Li F (2010) Pharmacokinetics of naringin and its metabolite naringenin in rats after oral administration of RhizomaDrynariae extract assayed by UPLC-MS/MS. Chin J Nat Med 8:40-46. https://doi.org/10.3724/SP.J.1009.2010.00040

100. Szeitz A, Edginton AN, Peng HT, Cheung B, Riggs KW A validated enantioselective assay for the determination of ibuprofen in human plasma using ultra performance liquid chromatography with tandem mass spectrometry (UPLC-MS/MS). Am J Anal Chem 2(210):47-58. https://doi.org/ 10.4236/ajac.2010.12007

101. Zhang WM, Li RM, Sun M, Hu DM, Qiu JE, Yan YH (2014) UPLC-MS/MS method for determination of avicularin in rat plasma and its application to a pharmacokinetic study. J Chromatogr B 965:107-111. https://doi.org/10. 1016/j.jchromb.2014.06.015

102. Wen C, Wang S, Huang $X$, Liu Z, Lin Y, Yang S, Ma J, Zhou Y, Wang X (2005) Determination and validation of hupehenine in rat plasma by UPLC-MS/MS and its application to pharmacokinetic study. Biomed Chromatogr 29:18051810. https://doi.org/10.1002/bmc.3499

103. He X, Zhang Y, Gao H, Li K, Zhang Y, Sun L, Tao G (2016) Simultaneous quantification of picfeltarraenins IA and IB in rat plasma by UPLC-MS/MS: application to a pharmacokinetic study. J Pharm Biomed Anal 120:32-37. https://doi.org/10.1016/j.jpba.2015.11.031
104. Cui Y, Lin X, Guan TT, Zhang Y, Tang X (2010) A new rapid ultraperformance liquid chromatography method for the pharmacokinetic and bioavailability study of diclofenac sodium aqueous injection and lipid microsphere injection in rats. Biomed Chromatogr 24:406-412. https://doi. org/10.1002/bmc.130.

105. Patel DP, Sharma P, Patel BM, Sanyal M, Singhal P, Shrivastav PS (2013) Analysis of 21-hydroxy deflazacort in human plasma by UPLC-MS/MS Application to a bioequivalence study in healthy volunteers. J Pharm Biomed Anal 85:213-217. https://doi.org/10.1016/j.jpba.2013.07.035

106. Qiu X, Lou D, Su D, Liu Z, Gao P, Zhang NS (2015) Simultaneous determination of acetaminophen and dihydrocodeine in human plasma by UPLC-MS/MS: Its pharmacokinetic application. J Chromatogr B 992:91-95. https://doi.org/10.1016/j.jchromb.2015.04.031

107. Qiu X, Zheng SL, Wang Y, Wang R, Ye L (2014) A Rapid and Simple UPLCMS-MS Method for Determination of Glipizide in Human Plasma and Its Application to Bioequivalence Study. J Chromatogr Sci 53:85-89. https://doi. org/10.1093/chromsci/bmu023

108. Cai S, Huo T, Li N, Xiong Z, Li F (2009) Lysophosphatidylcholine-biomarker of metformin action: studied using UPLC/MS/MS. Biomed Chromatogr 23: 782-786. https://doi.org/10.1002/bmc.1185

109. Jain R, Lukram O, Dwivedi A (2011) Ultra-performance liquid chromatography electrospray ionization-tandem mass spectrometry method for the estimation of miglitol in human plasma using metformin as the internal standard. Drug Test Anal. 3:255-262

110. Zhang JF, Sha CF, Sun Y, Gai YY, Sun JY, Han JB, Shao X, Sha CN, Li YX, Liu WH (2013) Ultra-high-performance liquid chromatography for the determination of exenatide in monkey plasma by tandem quadrupole mass spectrometry. J Pharm Anal 3:235-240. https://doi.org/10.1016/j.jpha.2012.12.007

111. Gu EM, Huang C, Liang B, Yuan L, Lan T, Hu G, Zhou H (2015) An UPLC-MS/ MS method for the quantitation of vortioxetine in rat plasma: application to a pharmacokinetic study. J Chromatogr B 997:70-74. https://doi.org/10. 1016/j.jchromb.2015.05.010

112. Denooz R, Mercerolle M, Lachâtre G, Charlier C (2010) Ultra-performance liquid chromatography-tandem mass spectrometry method for the determination of bupropion and its main metabolites in human whole blood. J Anal Toxicol 34:280-286

113. Qin F, Li N, Qin T, Zhang Y, Li F (2010) Simultaneous quantification of venlafaxine and O-desmethylvenlafaxine in human plasma by ultra performance liquid chromatography-tandem mass spectrometry and its application in a pharmacokinetic study. J Chromatogr B. 878:689-694. https://doi.org/10.1016/j.jchromb.2010.01.007

114. Bhatt M, Shah S (2010) Solid-phase extraction and analysis of paroxetine in human plasma by ultra-performance liquid chromatography-electrospray ionization mass spectrometry. Biomed Chromatogr 24:209-215. https://doi. org/10.1002/bmc.1275.

115. Karinen R, Vindenes V, Hasvold I, Olsen KM, Christophersen AS, Oiestad E (2015) Determination of a selection of anti-epileptic drugs and two active metabolites in whole blood by reversed phase UPLC-MS/MS and some examples of application of the method in forensic toxicology cases. Drug Test Anal 7:634-644

116. Proença P, Franco JM, Mustra C, Monteiro C, Costa J, Real FC, Vieira DN (2013) UPLC-MS/MS determination in blood of a mixed-drug fatal intoxication: a case report. Forensic Sci Int 227:85-89. https://doi.org/10. 1016/j.forsciint.2012.10.038

117. Bhatt M, Shah S (2015) Rapid ultra-performance liquid chromatographytandem mass spectrometry method for quantification of Oxcarbazepine and its metabolite in human plasma. Biomed Chromatogr 25:751-759

118. Marin SJ, Roberts M, Wood M, McMillin GA (2012) Sensitive UPLC-MSMS assay for 21 benzodiazepine drugs and metabolites, zolpidem andzopiclone in serum or plasma. J AnalToxicol 36:472-476. https://doi. org/10.1093/jat/bks059

119. Liang F, Terry AV, Bartlett MG (2012) Determination of aripiprazole in rat plasma and brain using ultra-performance liquid chromatography/ electrospray ionization tandem mass spectrometry. Biomed Chromatogr 26: 1325-1332. https://doi.org/10.1002/bmc.2698

120. Junnotula $V$, Licea-Perez H (2013) Development and validation of a simple and sensitive method for quantification of levodopa and carbidopa in rat and monkey plasma using derivatization and UPLC-MS/MS. J Chromatogr B 926:47-53. https://doi.org/10.1016/j.jchromb.2013.03.004

121. Zhang $Y$, Tingley FD, Tseng E, Tella M, Yang X, Groeber E, Liu J, Li W, Schmidt CJ, Steenwyk R (2012) Development and validation of a sample 
stabilization strategy and a UPLC-MS/MS method for the simultaneous quantitation of acetylcholine (ACh), histamine (HA), and its metabolites in rat cerebrospinal fluid (CSF). J Chromatogr B 879:2023-2033. https://doi.org/ 10.1016/.j.jhromb.2011.05.030

122. Chunduri RHB, Dannana GS (2016) Development and validation of a high throughput UPLC-MS/MS method for simultaneous quantification of esomeprazole, rabeprazole and levosulpiride in human plasma. J Pharm Anal 6:190-198

123. Baietto L, Calcagno A, Motta I, Baruffi K, Poretti V, Di PG, Bonora S, D'avolio A (2015) A UPLC-MS-MS method for the simultaneous quantification of firstline antituberculars in plasma and in PBMCs. J Antimicrob Chemother 70: 2572-2575. https://doi.org/10.1093/jac/dkv148

124. Hampel D, York ER, Allen LH (2012) Ultra-performance liquid chromatography tandem mass-spectrometry (UPLC-MS/MS) for the rapid, simultaneous analysis of thiamin, riboflavin, flavin adenine dinucleotide, nicotinamide and pyridoxal in human milk. J Chromatogr B 903:7-13. https://doi.org/10.1016/j.jchromb.2012.06.024

125. Jacobs BA, Rosing H, Vries ND, Meulendijks D, Henricks LM, Schellens JH, Beijnen JH (2016) Development and validation of a rapid and sensitive UPLC-MS/MS method for determination of uracil and dihydrouracil in human plasma. J Pharm Biomed Anal 126:75-82. https://doi.org/10.1016/j. jpba.2016.04.039

126. Upadhyay V, Trivedi V, Shah G, Yadav M, Shrivastav PS (2012) Rapid and sensitive UPLC-MS-MS determination of Tacrolimus in Wistar rats and human blood. J Chromatogr Sci 52:59-67. https://doi.org/10.1093/ chromsci/bms205

127. Cao S, Ni B, Feng L, Yin X, Dou H, Fu J, Lin J, Ni J (2014) Simultaneous Determination of Typhaneoside and Isorhamnetin-3-O-Neohesperidoside in rats after oral administration of pollen Typhae extract by UPLC-MS/MS. J Chromatogr Sci 53:866-871. https://doi.org/10.1093/chromsci/bmu132.

128. Upadhyay V, Trivedi V, Shah G, Yadav M, Shrivastav PS (2014) Determination of mycophenolic acid in human plasma by ultra performance liquid chromatography tandem mass spectrometry. J Pharm Anal 4:205-216

129. Radwan MA, Bawazeer GA, Aloudah NM, AlQuadeib BT, Aboul-Enein HY (2012) Determination of free and total warfarin concentrations in plasma using UPLC MS/MS and its application to a patient samples. BiomedChromatogr 26:6-11. https://doi.org/10.1002/bmc.1616

130. Yang X, Liu S, Sun J, Liu X, Sun Y, He Z (2009) UPLC for the determination of clopidogrel in dog plasma by tandem quadrupole MS: application to a pharmacokinetic study. Chromatographia 70:259-263. https://doi.org/10. 1365/s10337-009-1109-9

131. Xiong Z, Sun X, Huo T, Li N, Zheng Y, Sun Y (2010) Development and validation of UPLC-MS/MS method for simultaneous determination of gestodene and ethinyl estradiol in rat plasma. Biomed Chromatogr 24:160168. https://doi.org/10.1002/bmc.1265.

132. Hu G, Xu RA, Dong YY, Wang YY, Yao WW, Chen ZC, Chen D, Bu T, Ge RS (2015) Simultaneous determination of liensinine, isoliensinine and neferine in rat plasma by UPLC-MS/MS and application of the technique to pharmacokinetic studies. J Ethno Pharmacol 163:94-98. https://doi.org/10. 1016/j.jep.2015.01.020

133. Rodríguez OP, Zapata-Morales JR, Moratilla AE, León-Cabrero MDD, Roque IT, Urizar JP (2015) Determination of Pinaverium bromide in human plasma by a sensitive and robust UPLC-MS-MS method and application to a pharmacokinetic study in Mexican subjects. J Chromatogr Sci 53:1373-1378. https://doi.org/10.1093/chromsci/bmv027

134. Liu Z, Jiang M, Lu X, Qin F, Song Y, Wen J, Li F (2012) Simultaneous determination of pimpinellin, isopimpinellin and phellopterin in rat plasma by a validated UPLC-MS/MS and its application to a pharmacokinetic study after administration of Toddaliaasiatica extract. J Chromatogr B 891:102-108. https://doi.org/10.1016/j.jchromb.2012.02.022

135. Zoerner AA, Batkai S, Suchy MT, Gutzki FM, Engeli S, Jordan J, Tsikas D (2012) Simultaneous UPLC-MS/MS quantification of the endocannabinoids 2-arachidonoyl glycerol (2AG), 1-arachidonoyl glycerol (1AG), and anandamide in human plasma: Minimization of matrix-effects, 2AG/1AG isomerization and degradation by toluene solvent extraction. J Chromatogr B 883:161-171. https://doi.org/10.1016/j.jchromb.2011.06.025

136. Huang X, Su S, Cui W, Liu P, Duan JA, Guo J, Li Z, Shang E, Qian D, Huang Z (2014) Simultaneous determination of paeoniflorin, albiflorin, ferulic acid, tetrahydropalmatine, protopine, typhaneoside, senkyunolide I in Beagle dogs plasma by UPLC-MS/MS and its application to a pharmacokinetic study after Oral Administration of ShaofuZhuyu Decoction. J Chromatogr B 962:75-81. https://doi.org/10.1016/j.jchromb.2014.05.032
137. Liu Y, Li X, Yang C, Tai S, Zhang X, Liu G (2012) UPLC-MS-MS method for simultaneous determination of caffeine, tolbutamide, metoprolol, and dapsone in rat plasma and its application to cytochrome P450 activity study in rats. J Chromatogr Sci 51:26-32. https://doi.org/10.1093/chromsci/bms100

138. Colón RK, Martínez MA, Silva-Torres LA, Chavez-Arias C, Negrón MM, ConteMiller MS, Oquendo JB (2012) Simultaneous determination of Xylazine, free morphine, codeine, 6-acetylmorphine, cocaine and benzoylecgonine in postmortem blood by UPLC-MS-MS. J Anal Toxicol 36:319-326. https://doi. org/10.1093/jat/bks024

139. Ma J, Wang S, Zhang M, Zhang Q, Zhou Y, Lin C, Lin G, Wang X (2015) Simultaneous determination of bupropion, metroprolol, midazolam, phenacetin, omeprazole and tolbutamide in rat plasma by UPLC-MS/MS and its application to cytochrome P450 activity study in rats. Biomed Chromatogr 29:1203-1212. https://doi.org/10.1002/bmc.3409

140. Chen X, Gu E, Wang S, Zheng X, Chen M, Wang L, Hu G, Cai JP, Zhou H (2015) Evaluation of the effects of Ketoconazole and Voriconazole on the pharmacokinetics of Oxcarbazepine and its main metabolite MHD in rats by UPLC-MS-MS. J Chromatogr Sci 541:334-342. https://doi.org/10.1093/ chromsci/bmv146.

141. Wang Y, Wen J, Zheng W, Zhao L, Fu X, Wang Z, Xiong Z, Li F, Xiao W (2015) Simultaneous determination of neochlorogenic acid, chlorogenic acid, cryptochlorogenic acid and geniposide in rat plasma by UPLC-MS/MS and its application to a pharmacokinetic study after administration of Reduning injection. Biomed Chromatogr 29:68-74. https://doi.org/10.1002/bmc.3241

142. Zhao J, Chen X, Wang C, Wang Y, Ma C, Li W, Bi K (2010) Simultaneous determination of Evodiamine and Rutaecarpine in rat plasma by UPLC-MSMS and its application in a pharmacokinetics study. Chromatographia 72: 187-191. https://doi.org/10.1365/s10337-010-1633-7

143. Qiu X, Zhao J, Wang Z, Xu Z, Xu RA (2014) Simultaneous determination of bosentan and glimepiride in human plasma by ultra performance liquid chromatography tandem mass spectrometry and its application to a pharmacokinetic study. J Pharm Biomed Anal 95:207-212. https://doi.org/10. 1016/j.jpba.2014.03.011

144. Li H, Xia X, Xue Y, Tang S, Xiao X, Li J, Shen J (2012) Simultaneous determination of amoxicillin and prednisolone in bovine milk using ultrahigh performance liquid chromatography tandem mass spectrometry. J Chromatogr B 900:59-63. https://doi.org/10.1016/j.jchromb.2012.05.031

145. Li G, Yang F, Liu M, Su X, Zhao M, Zhao L (2016) Development and application of a UPLC-MS/MS method for simultaneous determination of fenofibric acid and berberine in rat plasma: application to the drug-drug pharmacokinetic interaction study of fenofibrate combined with berberine after oral administration in rats. Biomed Chromatogr 30:1075-1082. https:// doi.org/10.1002/bmc.3652.

146. Pan J, Zhang C, Zhang Z, Li G (2014) Review of online coupling of sample preparation techniques with liquid chromatography. Analytica chimica acta 815:1-15. https://doi.org/10.1016/j.aca.2014.01.017

147. Ludvigsson JW, Andersson T, Kjellberg V (2016) A new method to identify hydrolytic degradants in drug substances with UPLC-MS using 180-labelled water. J Pharm Biomed Anal 122:9-15. https://doi.org/10.1016/j.jpba.2016.01.041

148. Otasevic B, Milovanović S, Zečević M, Golubović J, Protić A (2014) UPLC method for determination of moxonidine and its degradation products in active pharmaceutical ingredient and pharmaceutical dosage form. Chromatographia 1:109-118. https://doi.org/10.1007/s10337-013-2580-x

149. Wingert NR, dos Santos NO, Nunes MA, Gomes P, Müller El, Flores EM, Steppe M (2016) Characterization of three main degradation products from novel oral anticoagulant rivaroxaban under stress conditions by UPLC-Q-TOF-MS/MS. J Pharm Biomed Anal 123:10-15. https://doi.org/10.1016/j.jpba.2016.01.053

150. Hubicka U, Żmudzki P, Talik P, Żuromska-Witek B, Krzek J (2013) Photodegradation assessment of ciprofloxacin, moxifloxacin, norfloxacin and ofloxacin in the presence of excipients from tablets by UPLC-MS/MS and DSC. Chem Cent J 7:133. https://doi.org/10.1186/1752-153X-7-133

151. Mei MK, Du Z, Xu R, Chen Y, Zhang H, Qu S (2012) Photocatalytic degradation of hexazinone and its determination in water via UPLC-MS/MS. J Hazard Mater 221:100-108. https://doi.org/10.1016/j.jhazmat.2012.04.018

152. Hubicka U, Żmudzki P, Żuromska-Witek B, Zajdel P, Pawłowski M, Krzek J (2012) Separation and characterization of ciprofloxacin, difloxacin, lomefloxacin, norfloxacin, and ofloxacin oxidation products under potassium permanganate treatment in acidic medium by UPLC-MS/MS. Talanta 109:91-100. https://doi.org/10.1016/j.talanta.2013.01.055

153. Siddiqui MR, Alothman ZA, Wabaidur SM (2014) Ultra performance liquid chromatography-mass spectrometric method for determination of 
ampicillin and characterization of its forced degradation products. J Chromatogr Sci 52:1273-1280

154. Reddy YK, Reddy GS, Veera KJ, Hotha KK (2012) A Stability Indicating UPLC Method for Finasteride and Its Related Impurities. Am J Anal Chem 3:737745. https://doi.org/10.4236/ajac.2012.311098P

155. Hotha KK, Patel T, Roychowdhury S, Subramanian V (2015) Identification, synthesis, and characterization of unknown impurity in the famotidine powder for oral suspension due to excipient interaction by UPLC-MS/MS and NMR. J Liq Chromatogr Rela Technol 38:977-985. doi:org/https://doi. org/10.1080/10826076.2014.999201.

156. Rao DD, Satyanarayana NV, Reddy AM, Sait SS, Chakole D, Mukkanti K (2010) A validated stability-indicating UPLC method for desloratadine and its impurities in pharmaceutical dosage forms. J Pharm Biomed Anal 51:736742. https://doi.org/10.1016/j.jpba.2009.09.016

157. Mowaka S, Mohamed D (2015) Novel contribution to the simultaneous analysis of certain hypoglycemic drugs in the presence of their impurities and degradation products utilizing UPLC-MS/MS. RSC Adv 5:60467-60481. https://doi.org/10.1039/C5RA11448A

158. Liu C, Hua Z, Bai Y (2015) Classification of illicit heroin by UPLC-Q-TOF analysis of acidic and neutral manufacturing impurities. Forensic Sci Int 257: 196-202. https://doi.org/10.1016/j.forsciint.2015.08.009

159. Bapatu HR, Maram RK, Cho WH, Pasagadugula VBR (2016) QbD Approach method development for estimation of Dabigatran Etexilate along with its impurities and identification of degradants in capsule dosage form. Am J Anal Che 7:494-524. https://doi.org/10.4236/ajac.2016.76047

160. Reddy AVB, Venugopal N, Madhavi G, Reddy KG, Madhavi V (2013) A selective and sensitive UPLC-MS/MS approach for trace level quantification of four potential genotoxic impurities in zolmitriptan drug substance. J Pharm Biomed Anal 84:84-89. https://doi.org/10.1016/j.jpba.2013.05.047

161. Thomas JL, Lincoln D, McCord BR (2013) Separation and detection of smokeless powder additives by ultra performance liquid chromatography with tandem mass spectrometry (UPLC/MS/MS). J Forensic Sci 58:609-615. https://doi.org/10.1111/1556-4029.12096

162. Koppala S, Panigrahi B, Raju SVN, Reddy KP, Reddy VR, Anireddy JS (2014) Development and validation of a simple, sensitive, selective and stabilityindicating RP-UPLC Method for the quantitative determination of ritonavir and its related compounds. J Chromatogr Sci 53:662-675. https://doi.org/10. 1093/chromsci/bmu097

163. Ding M, Lu J, Zhao C, Zhang S, Zhao Y (2016) Determination of 25-OCH 3-PPD and the related substances by UPLC-MS/MS and their cytotoxic activity. J Chromatogr B 1022:274-280. https:/doi.org/10.1016/j.jchromb.2016.04.031

164. Chrial columns. http://www.ymc.co.jp/en/columns/chiral_art/ Accessed 30 November 2018.

165. Baranowska I, Hejniak J, Magiera S (2016) Simultaneous Chiral Separation of Flavanone, Naringenin, and Hesperetin Enantiomers by RP-UHPLC-DAD. Chirality 28:147-152. https://doi.org/10.1002/chir.22559

166. Baranowska I, Hejniak J, Magiera S (2016) Development and validation of a RP-UHPLC-ESI-MS/MS method for the chiral separation and determination of flavanone, naringenin and hesperetin enantiomers. Talanta 1(159):181188. https://doi.org/10.1016/j.talanta.2016.06.020

167. Li L, Lurie IS (2015) Regioisomeric and enantiomeric analyses of 24 designer cathinones and phenethylamines using ultra high performance liquid chromatography and capillary electrophoresis with added cyclodextrins. Forensic Sci Int 1(254):148-157. https://doi.org/10.1016/j.forsciint.2015.06.026

168. Ramisetti NR, Arnipalli MS, Nimmu NV, Bondigalla R (2017) UHPLC determination of besifloxacin enantiomers on immobilized amylose tris (3, 5-dichlorophenylcarbamate) chiral stationary phase. Chromatographia 80: 1509-1515. https://doi.org/10.1007/s10337-017-3346-7

169. Regalado EL, Schafer W, McClain R, Welch CJ (2013) Chromatographic resolution of closely related species: separation of warfarin and hydroxylated isomers. J Chromatogr A1 1314:266-275. https://doi.org/10. 1016/j.chroma.2013.07.092

170. Regalado EL, Helmy R, Green MD, Welch CJ (2014) Chromatographic resolution of closely related species: drug metabolites and analogs. J Sep Sci 37:1094-1102. https://doi.org/10.1002/jssc.201400038

171. Balaji N, Sultana S (2017) Reversed-phase UHPLC enantiomeric separation of rasagiline salts using a Chiralpak ${ }^{\otimes}$ AGP Column. Sci Pharm 85:26. https://doi. org/10.3390/scipharm85030026

172. Yang J, Wang Y, Pan L, Li N, Lu X, Guan J, Cheng M, Li F (2009) Enantioselective determination of trantinterol in rat plasma by ultra performance liquid chromatography-electrospray ionization mass spectrometry after derivatization. Talanta 79:1204-1208. https://doi.org/10. 1016/j.talanta.2009.03.036

173. Wang G, Hsieh Y, Cheng KC, Morrison RA, Venkatraman S, Njoroge FG, Heimark L, Korfmacher WA (2007) Ultra-performance liquid chromatography/tandem mass spectrometric determination of diastereomers of SCH 503034 in monkey plasma. J Chromatogr B 852:92100. https://doi.org/10.1016/j.jchromb.2006.12.038

174. Malati V, Reddy AR, Mukkanti K, Suryanarayana MV (2012) A novel reverse phase stability indicating RP-UPLC method for the quantitative determination of fifteen related substances in Ranolazine drug substance and drug product. Talanta 97:563-573. https://doi.org/10.1016/j.talanta.2012.03.067

175. Raju TS, Kalyanaraman L, Reddy W, Swamy PY (2012) Development and validation of an UPLC method for the rapid separation of positional isomers and potential impurities of rivastigmine hydrogen tartrate in drug substance and drug product. J Liq Chromatogr Relat Technol 35(7):896-911. https:// doi.org/10.1080/10826076.2011.613143

176. Zhang Q, Wang D, Zhang M, Zhao Y, Yu Z (2017) The determination of 2-(2hydroxypropanamido) benzoic acid enantiomers and their corresponding prodrugs in rat plasma by UHPLC-MS/MS and application to comparative pharmacokinetic study after a single oral dose. J Chromatogr B 1041:175182. https://doi.org/10.1016/j.jchromb.2016.11.017

177. Jin H, Thangadurai TD, Jo SC, Jin D, Cui S, Lee YI (2012) On-line chiral analysis of benzylmercapturic acid and phenylmercapturic acid in human urine using UPLC-QToF mass spectrometry with the kinetic method. Microchem J 103:170-176. https://doi.org/10.1016/j.microc.2012.03.003

178. Reyes-Reyes ML, Roa-Morales G, Melgar-Fernández R, Reyes-Pérez H, GómezOliván LM, Gonzalez-Rivas N, Bautista-Renedo J, Balderas-Hernández P (2015) Chiral recognition of abacavir enantiomers by (2-hydroxy) propyl- $\beta$ cyclodextrin: UHPLC, NMR and DFT studies. J InclPhenomMacrocyclChem 82:373-382. https://doi.org/10.1007/s10847-015-0499-6

179. Monfort N, Martínez L, Bergés R, Segura J, Ventura R (2015) Screening method for stimulants in urine by UHPLC-MS/MS: identification of isomeric compounds. Drug Test Anal 7:819-830. https://doi.org/10.1002/dta.1776

180. Zhao J, Shin $Y$, Jin $Y$, Jeong KM, Lee J (2017) Determination of enantiomericvigabatrin by derivatization with diacetyl-L-tartaric anhydride followed by ultra-high performance liquid chromatography-quadrupoletime-of-flight mass spectrometry. J Chromatogr B 1040:199-207. https://doi. org/10.1016/j.jchromb.2016.11.016

181. Pan X, Dong F, Chen Z, Xu J, Liu X, Wu X, Zheng Y (2017) The application of chiral ultra-high-performance liquid chromatography tandem mass spectrometry to the separation of the zoxamide enantiomers and the study of enantioselective degradation process in agricultural plants. J Chromatogr A 1525:87-95. https://doi.org/10.1016/j.chroma.2017.10.016

\section{Publisher's Note}

Springer Nature remains neutral with regard to jurisdictional claims in published maps and institutional affiliations.

\section{Submit your manuscript to a SpringerOpen ${ }^{\circ}$ journal and benefit from:}

- Convenient online submission

- Rigorous peer review

- Open access: articles freely available online

- High visibility within the field

- Retaining the copyright to your article

Submit your next manuscript at $>$ springeropen.com 